\title{
The Dietary Flavonoid Kaempferol Mediates Anti-Inflammatory Responses via the Src, Syk, IRAK1, and IRAK4 Molecular Targets
}

\author{
Shi Hyoung Kim,, Jae Gwang Park, ${ }^{1}$ Jongsung Lee, ${ }^{2}$ Woo Seok Yang, \\ Gye Won Park, ${ }^{3}$ Han Gyung Kim, ${ }^{1}$ Young-Su Yi, ${ }^{1}$ Kwang-Soo Baek, ${ }^{1}$ Nak Yoon Sung, \\ Muhammad Jahangir Hossen, ${ }^{1,4}$ Mi-nam Lee, ${ }^{5}$ Jong-Hoon Kim, ${ }^{6}$ and Jae Youl Cho ${ }^{1}$ \\ ${ }^{1}$ Department of Genetic Engineering, Sungkyunkwan University, Suwon 440-746, Republic of Korea \\ ${ }^{2}$ Department of Dermatological Health Management, Eulji University, Seongnam, Republic of Korea \\ ${ }^{3}$ Department of Food Science and Biotechnology, Sungkyunkwan University, Suwon 440-746, Republic of Korea \\ ${ }^{4}$ Department of Animal Science, Patuakhali Science and Technology University, Patuakhali 8602, Bangladesh \\ ${ }^{5}$ Department of Food and Nutrition, School of Food Service Industry, Chungkang College of Cultural Industries, \\ Icheon 467-744, Republic of Korea \\ ${ }^{6}$ Department of Veterinary Physiology, College of Veterinary Medicine, Biosafety Research Institute, \\ Chonbuk National University, Jeonju 561-756, Republic of Korea \\ Correspondence should be addressed to Jong-Hoon Kim; jhkim1@jbnu.ac.kr and Jae Youl Cho; jaecho@skku.edu
}

Received 27 December 2014; Revised 8 March 2015; Accepted 9 March 2015

Academic Editor: Tânia Silvia Fröde

Copyright (C) 2015 Shi Hyoung Kim et al. This is an open access article distributed under the Creative Commons Attribution License, which permits unrestricted use, distribution, and reproduction in any medium, provided the original work is properly cited.

Even though a lot of reports have suggested the anti-inflammatory activity of kaempferol (KF) in macrophages, little is known about its exact anti-inflammatory mode of action and its immunopharmacological target molecules. In this study, we explored anti-inflammatory activity of KF in LPS-treated macrophages. In particular, molecular targets for KF action were identified by using biochemical and molecular biological analyses. KF suppressed the release of nitric oxide $(\mathrm{NO})$ and prostaglandin $\mathrm{E}_{2}\left(\mathrm{PGE}_{2}\right)$, downregulated the cellular adhesion of U937 cells to fibronectin (FN), neutralized the generation of radicals, and diminished mRNA expression levels of inflammatory genes encoding inducible NO synthase (iNOS), TNF- $\alpha$, and cyclooxygenase- (COX-) 2 in lipopolysaccharide- (LPS-) and sodium nitroprusside- (SNP-) treated RAW264.7 cells and peritoneal macrophages. KF reduced NF- $\kappa$ B (p65 and p50) and AP-1 (c-Jun and c-Fos) levels in the nucleus and their transcriptional activity. Interestingly, it was found that Src, Syk, IRAK1, and IRAK4 responsible for NF- $\kappa$ B and AP-1 activation were identified as the direct molecular targets of $\mathrm{KF}$ by kinase enzyme assays and by measuring their phosphorylation patterns. KF was revealed to have in vitro and in vivo antiinflammatory activity by the direct suppression of Src, Syk, IRAK1, and IRAK4, involved in the activation of NF- $\kappa$ B and AP-1.

\section{Introduction}

Inflammation is an innate immune response that protects the human body from chemicals and infectious microorganisms [1]. This response is comprised of pain, heat, swelling, and redness. At the molecular level, various cytokines (e.g., tumor necrosis factor- (TNF-) $\alpha$ ), hydrolytic enzymes, toxic molecules (e.g., nitric oxide (NO) and reactive oxygen species $(\mathrm{ROS})$ ), and mediators (e.g., prostaglandin $\mathrm{E}_{2}\left(\mathrm{PGE}_{2}\right)$ ) are released from inflammatory cells $[2,3]$. Many complicated biochemical processes are required to trigger the cellular inflammatory response. The activation of pattern recognition receptors (e.g., Toll-like receptors (TLRs)) is reliant on association with counter ligands such as lipopolysaccharide (LPS) and peptidoglycan (PGN) [4]. Then, many different intracellular signaling cascades are initiated via two major adaptor molecules (Toll/Il-1 receptor-domain-containing, adapterinducing interferon- $\beta$ (TRIF), and myeloid differentiation response gene 88 (MyD88)) generated to eventually activate inflammation-regulatory transcription factors including 
nuclear factor- (NF-) $\kappa \mathrm{B}$ and activator protein- (AP-) 1 to express inflammation-mediating genes encoding inducible NO synthase (iNOS), cyclooxygenase-2 (COX-2), cytokines, and chemokines $[5,6]$.

Even though inflammatory events are one of critical defensive ways in human body, prolonged levels of inflammation somehow cause organ damage leading to loss of functions and their related diseases such as cancer, diabetes, and atherosclerosis $[7,8]$. However, the knowledge as to how inflammation can induce tissue damage is still not fully understood. Oxidative stress accompanied by sustained inflammation is considered as major causing factor in generation of organ damage. This led us to the fact that antioxidative agents could be functional in preventing such damage [9]. Since toxic radicals are not the only factor inducing inflammation-mediated functional damage, it is needed that other pathological pathways such as cellular inflammatory signaling should be also targeted for treating chronic inflammatory diseases $[10,11]$. These points indicate that antiinflammatory remedy to treat acute and chronic inflammatory responses should include additional pharmacological action to radical scavenging activity.

Kaempferol (3,5,7-trihydroxy-2-(4-hydroxyphenyl)-4H1-benzopyran-4-one, KF, Figure 1(a)) is a representative polyphenolic compound in nature [12]. This compound is highly contained in most edible herbal plants such as tea, fruits, and vegetables [13]. These include Allium cepa (onion), Camellia sinensis (tea), Citrus paradisi (grapefruit), Fragaria vesca (strawberry), Lactuca sativa (lettuce), and Morinda citrifolia (Indian mulberry) as well as medicinal plants such as Cerbera manghas [13-15]. Owing to numerous pharmacological studies due to its popularity, it has been reported that this compound is able to display antioxidative, anticancer, anti-inflammatory, and antiaging properties [16-18]. By molecular approaches of KF, some of KF target proteins have been identified. For example, kaempferol was revealed to be skin protective by suppressing kinase activities of ribosomal S6 kinase, mitogen, and stress-activated protein kinase, which are activated by UV irradiation, via competition with ATP at ATP-binding pocket [19]. It was also proposed that kaempferol is effective in inhibiting cancer progression through antagonizing selective estrogen-related receptors alpha and gamma [20]. Furthermore, epidermal growth factor-induced neoplastic transformation of mouse epidermal JB6 P+ cells was reduced by KF through lowering phosphatidylinositol 3-kinase (PI3K) activity [21]. In contrast to these results, molecular targets identified in antiinflammatory action of KF were not reported yet, although $\mathrm{NF}-\kappa \mathrm{B}$ and AP- 1 are known as target pathways of KF [22-26]. Thus, most of reports simply suggested that the phosphorylation of mitogen activated protein kinases (MAPK) such as extracellular-signal-regulated kinase 1/2 (ERK1/2), p38, and c-Jun N-terminal kinase (JNK) and the phosphorylation of inhibitor of $\kappa \mathrm{B}$ kinase $(\mathrm{IKK} \alpha / \beta)$, which were critical steps for NF- $\kappa$ B and AP- 1 activations, were remarkably reduced by $\mathrm{KF}$ treatment in cellular and tissue levels [22]. In view of the fact that flavonoids can be considered as anti-inflammatory remedy due to their multiple pharmacological actions, it is important for us to understand as to which molecular targets can be contributed to their anti-inflammatory responses. In the present study, therefore, we aimed to expand the understanding levels of KF-mediated anti-inflammatory process by identifying the molecular targets regulating LPS-stimulated macrophages.

\section{Materials and Methods}

2.1. Materials. KF, indomethacin (Indo), prednisolone (Pred), $\mathrm{N}$-nitro-L-arginine-methyl ester (L-NAME), ranitidine, polyethylenimine (PEI), arachidonic acid, 3-(4,5-dimethylthiazol-2-yl)-2,5-diphenyltetrazolium bromide (a tetrazole) (MTT), sodium nitroprusside (SNP), sodium dodecyl sulfate (SDS), dimethyl sulfoxide (DMSO), pam3CSK, dihydrorhodamine (DHR) 123, and lipopolysaccharide (LPS, E. coli 0111:B4) were purchased from Sigma Chemical Co. (St. Louis, MO). Piceatannol (Picea), PP2, SB203580 (SB), and SP600125 (SP) were obtained from Calbiochem (La Jolla, CA). The enzyme immune assay (EIA) kits that were used to determine $\mathrm{PGE}_{2}$ levels were purchased from Amersham (Little Chalfont, Buckinghamshire, UK). Fibronectin (FN), fetal bovine serum (FBS), penicillin, streptomycin, TRIzol Reagent, and RPMI1640 were obtained from GIBCO (Grand Island, NY). RAW264.7, U937, and HEK293 cells were purchased from ATCC (Rockville, MD). All other chemicals used in this study were of analytical grade of Sigma Chemical Co. Phosphospecific or total antibodies that were raised against p65, p50, cFos, c-Jun, inhibitor of $\kappa \mathrm{B} \alpha(\mathrm{I} \kappa \mathrm{B} \alpha)$, Src, spleen tyrosine kinase (Syk), p85, ERK, JNK, p38, mitogen activated protein kinase (MKK)3, MKK4, interleukin-1 receptor-associated kinase 1 (IRAK1), IRAK4, transforming growth factor $\beta$-activated kinase-1 (TAK1), Akt, I $\kappa \mathrm{B} \alpha, \mathrm{Myc}$, lamin $\mathrm{A} / \mathrm{C}$, and $\beta$-actin were obtained from Cell Signaling (Beverly, MA).

2.2. Construction of Expression Vectors. All constructs were prepared by amplification using a typical culture method with competent E. coli (DH5 $\alpha)$. FLAG-MyD88, CFP-TRIF, and Myc-Syk constructs were used as reported previously [27]. Luciferase constructs containing binding sites for NF- $\kappa \mathrm{B}$ and AP-1 were used as reported previously [28]. All constructs were confirmed by automated DNA sequencing.

2.3. Mice. Six-week-old C57BL/6 mice were purchased from DAEHAN BIOLINK (Chungbuk, Republic of Korea) and were housed in groups of 6-8 mice under a $12 \mathrm{~h}$ light/dark cycle (lights on at $6 \mathrm{am}$ ). Water and pellet diets (Samyang, Daejeon, Republic of Korea) were supplied ad libitum. Animals were cared for in accordance with the guidelines issued by the National Institute of Health for the Care and Use of Laboratory Animals (NIH Publication 80-23, revised in 1996). Studies were performed in accordance with guidelines established by the Institutional Animal Care and Use Committee at Sungkyunkwan University (Suwon, Republic of Korea; Approval ID: SKKUBBI 13-6-4).

2.4. Preparation of Peritoneal Macrophages. Peritoneal exudates were obtained from C57BL/6 male mice (7-8 weeks old and weighing $17-21 \mathrm{~g}$ ) by lavage 4 days after intraperitoneal 
<smiles>O=c1c(O)c(-c2ccc(O)cc2)oc2cc(O)cc(O)c12</smiles>

(a)
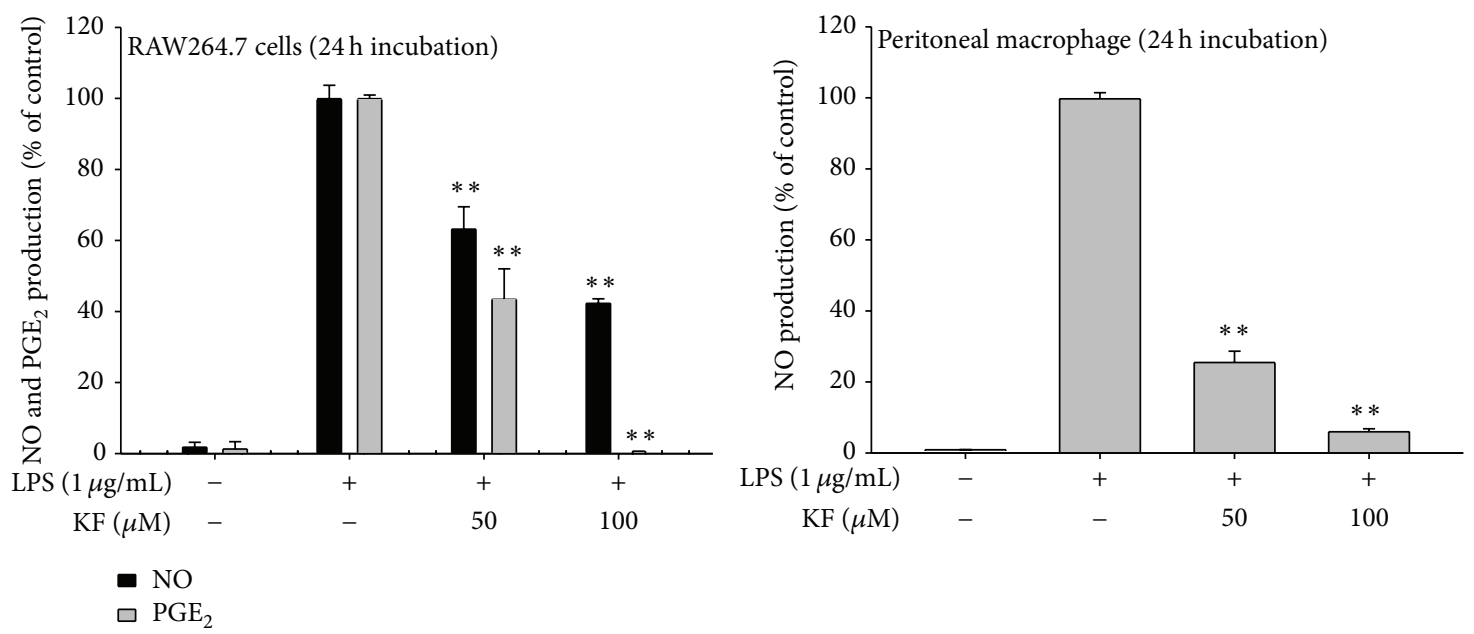

(b)
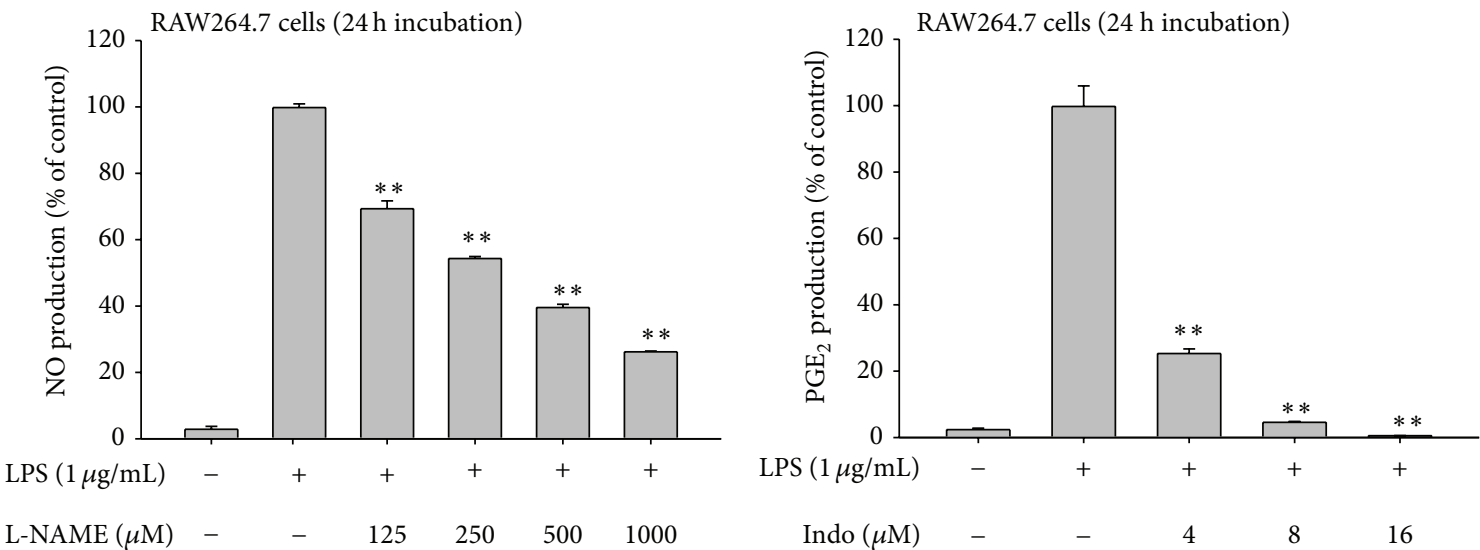

(c)
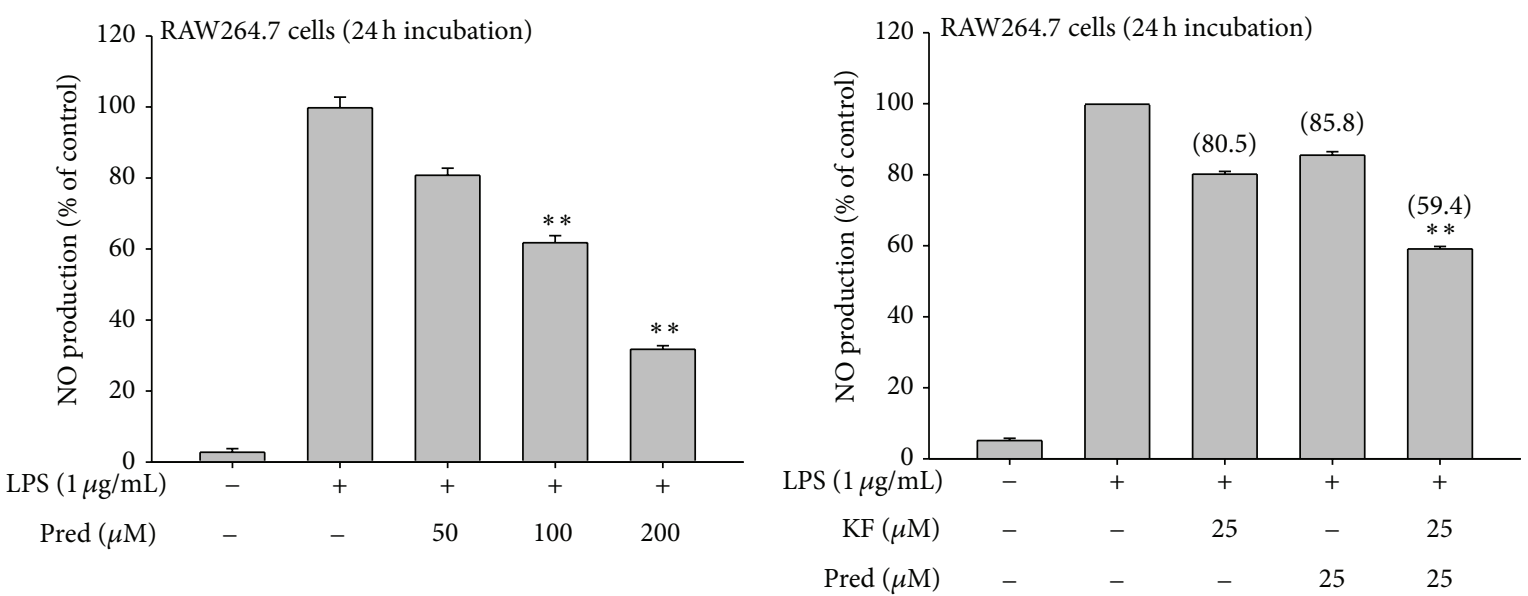

(d)

Figure 1: Continued. 


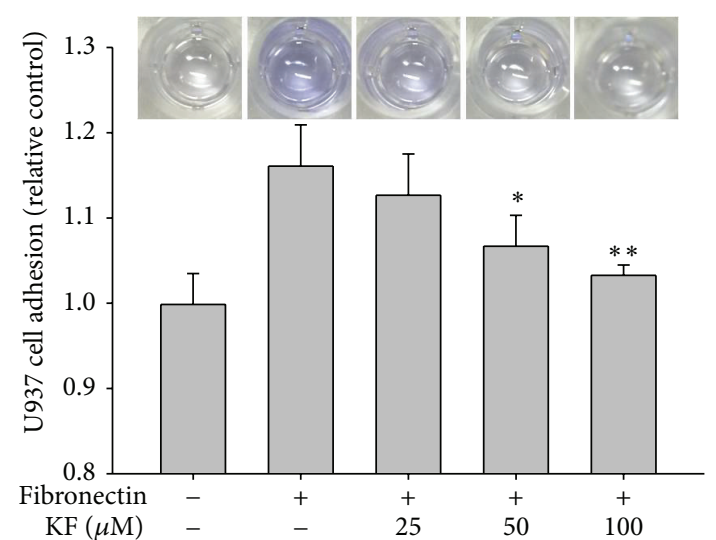

(e)

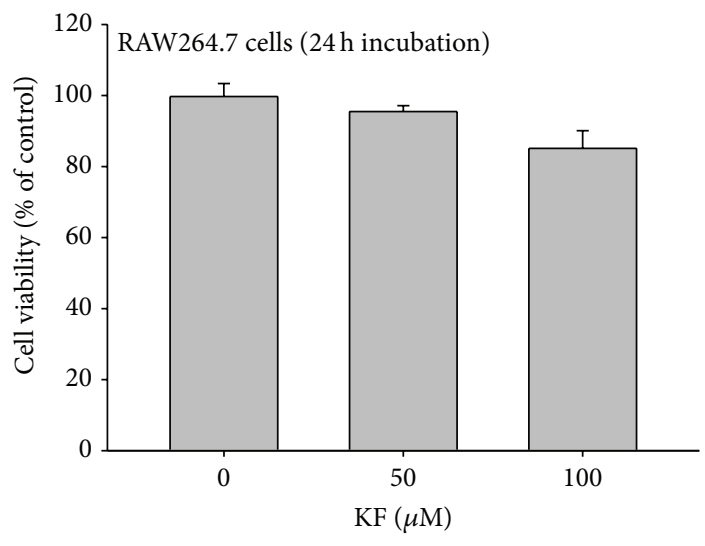

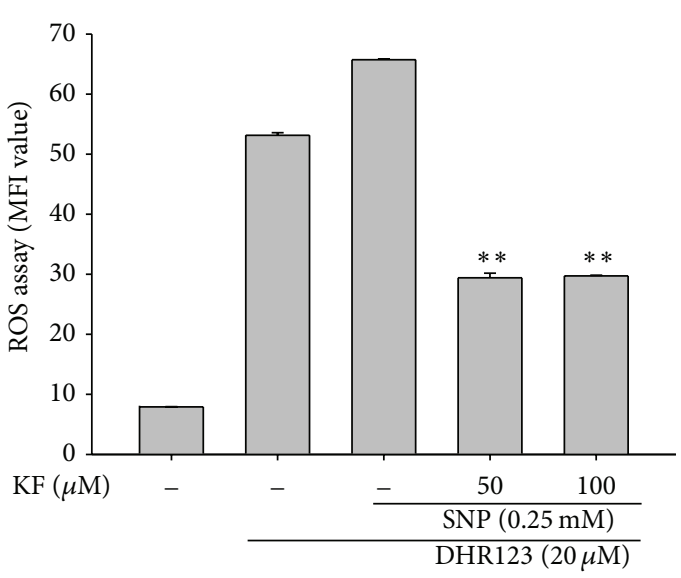

(f)

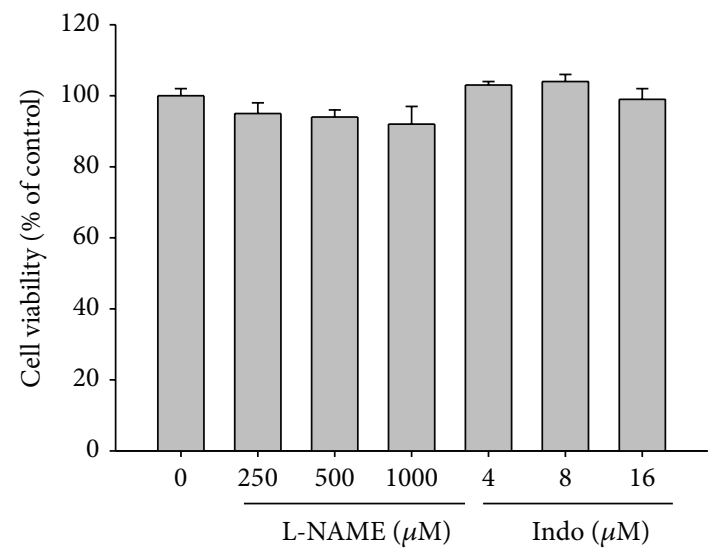

(g)

FIGURE 1: The effects of KF on the production of NO, PGE , and TNF- $\alpha$ in macrophages, the neutralization of ROS, and macrophage viability. (a) Chemical structure of KF. (b, c, and d) RAW264.7 cells or peritoneal macrophages $\left(1 \times 10^{6}\right.$ cells $\left./ \mathrm{mL}\right)$ were incubated with LPS $(1 \mu \mathrm{g} / \mathrm{mL})$ under either single treatment (b, c, and d left panel) of KF, Indo, L-NAME, and Pred or combination treatment ( $\mathrm{d}$ right panel) of KF with Pred for $24 \mathrm{~h}$. The supernatants were collected and the $\mathrm{NO}$ or $\mathrm{PGE}_{2}$ concentrations in the supernatants were determined using the Griess assay or EIA. (e) Effect of KF on cell-matrix protein adhesion was evaluated by using fibronectin (FN) coated conditions. U937 cells were pretreated with $\mathrm{KF}$ and seeded on FN $(50 \mu \mathrm{g} / \mathrm{mL})$ coated plates for $4 \mathrm{~h}$. The number of attached cells was determined by crystal violet staining. (f) RAW264.7 cells preincubated with KF were treated with DHR123 $(20 \mu \mathrm{M})$ in the presence or absence of SNP $(0.25 \mathrm{mM})$ for $2 \mathrm{~h}$. The level of radicals was determined by flow cytometric analysis. (g) RAW264.7 cells $\left(1 \times 10^{6}\right.$ cells $\left./ \mathrm{mL}\right)$ were treated with KF or standard compounds (Indo and L-NAME) for $24 \mathrm{~h}$. Cell viability was evaluated using the MTT assay. All of the data are expressed as the mean \pm SD of experiments that were performed with six samples. ${ }^{*} P<0.05$ and ${ }^{* *} P<0.01$ compared to the normal or control groups.

injection of $1 \mathrm{~mL}$ of sterile $4 \%$ thioglycollate broth (Difco Laboratories, Detroit, MI) as reported previously [29]. After the exudates were washed with RPMI1640 medium containing $2 \%$ FBS, peritoneal macrophages $\left(1 \times 10^{6}\right.$ cells $\left./ \mathrm{mL}\right)$ were plated in $100 \mathrm{~mm}$ tissue culture dishes for $4 \mathrm{~h}$ at $37^{\circ} \mathrm{C}$ in a $5 \%$ $\mathrm{CO}_{2}$ humidified atmosphere.

2.5. Cell Culture and Drug Preparation. RAW264.7 cells, a murine macrophage cell line, and HEK293 cells were maintained in RPMI1640 media supplemented with $100 \mathrm{U} / \mathrm{mL}$ of penicillin, $100 \mu \mathrm{g} / \mathrm{mL}$ of streptomycin, and $10 \%$ FBS. The cells were grown at $37^{\circ} \mathrm{C}$ and $5 \% \mathrm{CO}_{2}$ in humidified air. The stock solutions of KF for the in vitro experiments were prepared using DMSO.
2.6. Determination of $\mathrm{NO}$ and $P G E_{2}$ Production. After preincubation of RAW264.7 cells or peritoneal macrophages $(1 \times$ $10^{6}$ cells $/ \mathrm{mL}$ ) for $18 \mathrm{~h}$, the cells were treated with KF (0 to $100 \mu \mathrm{M})$ or standard compounds (Pred, L-NAME or Indo) for $30 \mathrm{~min}$ and then further incubated with LPS $(1 \mu \mathrm{g} / \mathrm{mL})$ for $24 \mathrm{~h}$. The inhibitory effects of $\mathrm{KF}$ on $\mathrm{NO}$ and $\mathrm{PGE}_{2}$ production were determined by analyzing $\mathrm{NO}$ and $\mathrm{PGE}_{2}$ levels using Griess reagents and an EIA kit, as previously described [30, 31].

2.7. Cell Adhesion Assay. A U937 cell-fibronectin (FN) adhesion assay was performed as reported previously $[32,33]$. U937 cells $\left(5 \times 10^{5}\right.$ cells/well $)$ pretreated with $\mathrm{KF}$ were seeded on a fibronectin $(50 \mu \mathrm{g} / \mathrm{mL})$ coated plate and incubated for 
$4 \mathrm{~h}$ [34]. After removing the unbound cells with PBS, the attached cells were treated with $0.1 \%$ of crystal violet for $15 \mathrm{~min}$. The OD at $570 \mathrm{~nm}$ was measured with a SpectraMax 250 microplate reader.

2.8. Determination of ROS Generation. The level of intracellular ROS was determined by a change in fluorescence resulting from the oxidation of the fluorescent probe, DHR123. Briefly, $5 \times 10^{5}$ RAW264.7 cells were exposed to KF for $30 \mathrm{~min}$. After incubation, cells were then incubated with SNP $(0.25 \mathrm{mM})$, an inducer of ROS production, at $37^{\circ} \mathrm{C}$ for $2 \mathrm{~h}$. Cells were incubated with $20 \mu \mathrm{M}$ of the fluorescent probe DHR123 for $1 \mathrm{~h}$ at $37^{\circ} \mathrm{C}$. The degree of fluorescence, corresponding to intracellular ROS, was determined using a FACScan flow cytometer (Becton-Dickinson, San Jose, CA), as reported previously [3, 33, 35]. Briefly, the RAW264.7 cells treated with KF, SNP, and DHR123 were washed with a staining buffer (containing $2 \%$ rabbit serum and $1 \%$ sodium azide in PBS) and incubated for a further $45 \mathrm{~min}$ on ice. After washing three times with staining buffer, stained cells were analyzed on a FACScan flow cytometer (Becton-Dickinson, San Jose, CA, USA).

2.9. Cell Viability Test. After preincubation of RAW 264.7 cells $\left(1 \times 10^{6}\right.$ cells $\left./ \mathrm{mL}\right)$ for $18 \mathrm{~h}$, KF $(0$ to $100 \mu \mathrm{M})$ or standard compounds (L-NAME or Indo) were added to the cell suspensions and incubated for $24 \mathrm{~h}$. The cytotoxic effects of KF were then evaluated using a conventional MTT assay, as previously reported [36-38]. Three hours prior to culture termination, $10 \mu \mathrm{L}$ of MTT solution $(10 \mathrm{mg} / \mathrm{mL}$ in phosphatebuffered saline, $\mathrm{pH}$ 7.4) was added, and the cells were continuously cultured until the termination of the experiment. The incubation was halted by the addition of 15\% SDS into each well, solubilizing the formazan. The absorbance at $570 \mathrm{~nm}\left(\mathrm{OD}_{570-630}\right)$ was measured using a SpectraMax 250 microplate reader (BioTex, Bad Friedrichshall, Germany).

\subsection{0. $m R N A$ Analysis Using Quantitative Polymerase Chain} Reactions. In order to determine cytokine mRNA expression levels, total RNA was isolated from LPS-treated RAW264.7 cells using TRIzol Reagent, according to the manufacturer's recommended instructions. Total RNA was stored at $-70^{\circ} \mathrm{C}$ until use. Semiquantitative RT reactions were conducted as previously reported $[39,40]$. Quantification of mRNA was performed by real-time RT-PCR with SYBR Premix Ex Taq according to the manufacturer's instructions (Takara, Shiga, Japan) using a real-time thermal cycler (Bio-Rad, Hercules, CA), as reported previously [41]. All of the primers (Bioneer, Daejeon, Republic of Korea) used are indicated in Table 1.

\subsection{Preparation of Cell Lysates and Nuclear Fractions for} Immunoblotting. RAW264.7 cells $\left(5 \times 10^{6}\right.$ cells $\left./ \mathrm{mL}\right)$ were washed 3 times in cold PBS containing $1 \mathrm{mM}$ sodium orthovanadate and lysed in lysis buffer $(20 \mathrm{mM}$ Tris- $\mathrm{HCl}, \mathrm{pH} 7.4$, $2 \mathrm{mM}$ EDTA, $2 \mathrm{mM}$ ethyleneglycotetraacetic acid, $50 \mathrm{mM} \beta$ glycerophosphate, $1 \mathrm{mM}$ sodium orthovanadate, $1 \mathrm{mM}$ dithiothreitol, $1 \%$ Triton $\mathrm{X}-100,10 \%$ glycerol, $10 \mu \mathrm{g} / \mathrm{mL}$ aprotinin, $10 \mu \mathrm{g} / \mathrm{mL}$ pepstatin, $1 \mathrm{mM}$ benzimide, and $2 \mathrm{mM}$ PMSF) for
TABLE 1: Real-time PCR primers used in this experiment.

\begin{tabular}{cl}
\hline Name & Sequence $\left(5^{\prime}\right.$ to $\left.3^{\prime}\right)$ \\
\hline Real-time PCR & \\
iNOS & \\
F & GGAGCCTTTAGACCTCAACAGA \\
R & TGAACGAGGAGGGTGGTG \\
TNF- $\alpha$ & TGCCTATGTCTCAGCCTCTTC \\
F & GAGGCCATTTGGGAACTTCT \\
R & \\
COX-2 & GGGAGTCTGGAACATTGTGAA \\
F & GCACATTGTAAGTAGGTGGACTGT \\
R & \\
GAPDH & CAATGAATACGGCTACAGCAAC \\
F & AGGGAGATGCTCAGTGTTGG \\
R & \\
\hline
\end{tabular}

$30 \mathrm{~min}$, with rotation, at $4^{\circ} \mathrm{C}$. The lysates were clarified by centrifugation at $16,000 \times \mathrm{g}$ for $10 \mathrm{~min}$ at $4^{\circ} \mathrm{C}$ and stored at $-20^{\circ} \mathrm{C}$ until needed.

Nuclear lysates were prepared using a three-step procedure [42]. After treatment, the cells were collected with a rubber policeman, washed with $1 \times \mathrm{PBS}$, and lysed in $500 \mu \mathrm{L}$ of lysis buffer containing $50 \mathrm{mM} \mathrm{KCl}, 0.5 \%$ Nonidet P-40, $25 \mathrm{mM}$ HEPES ( $\mathrm{pH} 7.8$ ), $1 \mathrm{mM}$ phenylmethylsulfonyl fluoride, $10 \mu \mathrm{g} / \mathrm{mL}$ leupeptin, $20 \mu \mathrm{g} / \mathrm{mL}$ aprotinin, and $100 \mu \mathrm{M}$ 1,4-dithiothreitol (DTT) on ice for $4 \mathrm{~min}$. Cell lysates were then centrifuged at $14,000 \mathrm{rpm}$ for $1 \mathrm{~min}$ in a microcentrifuge. During the second step, the pellet (the nuclear fraction) was washed once with wash buffer without Nonidet P-40. During the final step, the nuclei were treated with an extraction buffer containing $500 \mathrm{mM} \mathrm{KCl}, 10 \%$ glycerol, and several other reagents that were contained in the lysis buffer. The nuclei/extraction buffer mixture was frozen at $-80^{\circ} \mathrm{C}$ and then thawed on ice and centrifuged at 14,000 rpm for $5 \mathrm{~min}$. The supernatant was collected as the nuclear extract.

Whole cell or nuclear lysates were then analyzed using immunoblotting. Proteins were separated on 10\% SDSpolyacrylamide gels and transferred by electroblotting to a polyvinylidene difluoride (PVDF) membrane. Membranes were blocked for $60 \mathrm{~min}$ in Tris-buffered saline containing 3\% FBS, $20 \mathrm{mM}$ NaF, $2 \mathrm{mM}$ EDTA, and $0.2 \%$ Tween 20 at room temperature. The membranes were incubated for $60 \mathrm{~min}$ with specific primary antibodies at $4^{\circ} \mathrm{C}$, washed 3 times with the same buffer, and incubated for an additional $60 \mathrm{~min}$ with HRP-conjugated secondary antibodies. The total and phosphorylated levels of p65, p50, c-Fos, c-Jun, I $\kappa \mathrm{B} \alpha$, Src, Syk, p85, ERK, JNK, p38, MKK3, MKK4, IRAK1, IRAK4, TAK1, Akt, $\mathrm{I} \kappa \mathrm{B} \alpha, \mathrm{Myc}$, lamin $\mathrm{A} / \mathrm{C}$, and $\beta$-actin were visualized using an ECL system (Amersham, Little Chalfont, Buckinghamshire, $\mathrm{UK})$, as reported previously [43].

2.12. DNA Transfection and Luciferase Reporter Gene Activity Assay. Overexpression experiment was performed with HEK293 cells $\left(1 \times 10^{6}\right.$ cells $\left./ \mathrm{mL}\right)$ by transfection of MycSyk $(1 \mu \mathrm{g} / \mathrm{mL})$ using the PEI method in 12 -well plates, as 
reported previously $[44,45]$. The cells were utilized for the experiments $24 \mathrm{~h}$ after transfection. KF was additionally treated to the cells before $12 \mathrm{~h}$ of termination. For reporter gene assay, HEK293 cells $\left(1 \times 10^{6}\right.$ cells $\left./ \mathrm{mL}\right)$ were transfected with $1 \mu \mathrm{g}$ of plasmids containing NF- $\kappa \mathrm{B}-\mathrm{Luc}$, or AP-1-Luc, as well as $\beta$-galactosidase, using the PEI method in 12-well plates, according to the procedure that was outlined in a previous report $[44,45]$. Luciferase assays were performed using the Luciferase Assay System (Promega, Madison, WI), as previously reported [46].

2.13. In Vitro Kinase Assay with Purified Enzymes. In order to evaluate the inhibition of the kinase activities of Src, Syk, IRAK1, or IRAK4 using purified enzymes, the kinase profiler service from Millipore (Billerica, MA) was used. Purified Src, Syk, IRAK1, or IRAK4 (human) (1-5 mU) were incubated with the reaction buffer in a final reaction volume of $25 \mu \mathrm{L}$. The reaction was initiated by the addition of MgATP. After incubation for $40 \mathrm{~min}$ at room temperature, the reaction was stopped by the addition of $5 \mathrm{~mL}$ of a $3 \%$ phosphoric acid solution. Ten microliters of the reaction was then spotted onto a P30 Filtermat and washed three times for $5 \mathrm{~min}$ in $75 \mathrm{mM}$ phosphoric acid and once in methanol prior to drying and scintillation counting.

2.14. Statistical Analyses. All of the data presented in this paper are expressed as the means \pm SD of experiments. For the statistical comparisons, the results were analyzed using either ANOVA/Scheffe's post hoc test or the KruskalWallis/Mann-Whitney test. A $P$ value $<0.05$ was considered to be a statistically significant difference. All of the statistical tests were carried out using the computer program SPSS (SPSS Inc., Chicago, IL). Similar experimental data were also observed using an additional independent set of in vitro experiments that was conducted using the same numbers of samples or mice.

\section{Results}

3.1. Effect of KF on the Inflammatory Response. KF (50 and $100 \mu \mathrm{M})$ inhibited the production of $\mathrm{NO}(26.7 \mu \mathrm{M}$ as nitrite) and $\mathrm{PGE}_{2}(3.4 \mathrm{ng} / \mathrm{mL})$ in LPS-treated RAW264.7 cells relative to basal levels of $\mathrm{NO}(0.53 \mu \mathrm{M})$ and $\mathrm{PGE}_{2}(0.098 \mathrm{ng} / \mathrm{mL})$ in resting cells up to $98 \%$ in a dose-dependent manner (Figure 1(b) left panel). Similarly, increased levels of NO $(55.2 \mu \mathrm{M})$ in LPS-stimulated peritoneal macrophages relative to basal levels $(0.39 \mu \mathrm{M})$ were also clearly reduced by $\mathrm{KF}$ (Figure 1(b) right panel). Standard compounds (Pred, LNAME, and Indo) also displayed a clear dose-dependent inhibitory pattern under the same $\mathrm{NO}$ and $\mathrm{PGE}_{2}$ production conditions (Figures 1(c) and 1(d) left panel), as reported previously [47], indicating that our experimental conditions were consistent with the literature. Interestingly, combination treatment (40.6\% as percentage inhibition) of KF with Pred displayed additive inhibitory activity compared to single treatment of these compounds (KF (19.5\%) and Pred (14.2\%)) (Figure $1(\mathrm{~d})$ right panel), indicating that the inhibitory mode of action by KF might be different from that of glucocorticoid drugs (e.g., prednisolone). Moreover, KF also dosedependently downregulated the adhesion of U937 cells to FN (Figure 1(e)). Finally, since KF is a representative antioxidant flavonoid, we also confirmed its radical scavenging activity using SNP-induced ROS generation in RAW264.7 cells. Expectedly, KF showed strong antioxidative activity at both 50 and $100 \mu \mathrm{M}$ (Figure 1(f)), suggesting that these doses of KF are pharmacologically effective. Finally, MTT assays were used to determine if $\mathrm{KF}$ and other drugs suppress the production of $\mathrm{NO}, \mathrm{PGE}_{2}$, and other radicals without altering cell cytotoxicity. As Figure 1(g) shows, there was no significant reduction in cell viability by the drugs, implying that the above effects were not derived by nonspecific cytotoxicity.

\subsection{Effect of KF on Transcriptional Activation of the Inflamma-} tory Response. Since KF blocked the release of inflammatory mediators from LPS-stimulated macrophages, we next examined whether the inhibition occurred at the transcriptional level. For this purpose, the mRNA levels of inflammatory genes were measured by real-time PCR. As Figure 2(a) depicts, KF inhibited the expression of genes encoding COX-2, TNF- $\alpha$, and iNOS in a dose-dependent manner. In agreement with this result, KF suppressed the nuclear levels of major transcription factors (c-Jun at 30, 60, and $120 \mathrm{~min}$; c-Fos at 30 and $60 \mathrm{~min}$; p65 at 15, 30, and $60 \mathrm{~min}$; and p50 at $120 \mathrm{~min}$ ) in LPS-treated RAW264.7 cells (Figure 2(b) left panel). At $60 \mathrm{~min}$, the nuclear levels of c-Jun, c-Fos, and p65 were reduced by $\mathrm{KF}$ in a dose-dependent manner as well (Figure 2(b) right panel). Based on luciferase reporter gene assays, it was revealed that the transcriptional regulatory activity of NF- $\kappa$ B and AP-1 was suppressed by 50 and $100 \mu \mathrm{M}$ of KF (Figure 2(c)), indicating that KF modulates the DNA binding ability of NF- $\kappa \mathrm{B}$ and AP-1.

\subsection{Effect of KF on Upstream Signaling for NF- $\kappa B$ and AP-1} Activation. After confirming that both the nuclear translocation of p 65 and p50 and their promoter binding activities were strongly suppressed (Figure 2), we next examined the effect of $\mathrm{KF}$ on upstream signaling for $\mathrm{NF}-\kappa \mathrm{B}$ activation. First, the time dependent inhibitory pattern of $\mathrm{I} \kappa \mathrm{B} \alpha$ phosphorylation was investigated $[39,48]$. Interestingly, $\mathrm{KF}$ decreased the phosphorylation of $\mathrm{I} \kappa \mathrm{B} \alpha$ at $5 \mathrm{~min}$ and marginally suppressed this activity at $30 \mathrm{~min}$ (Figure 3(a)). Since the early phosphorylation of $\mathrm{I} \kappa \mathrm{B} \alpha$ is mediated by the early activation of protein tyrosine kinases Syk and Src, we confirmed the inhibitory activity of KF on the autophosphorylation patterns of Syk and Src. As Figure 3(b) shows, the phosphorylation of Src and Syk was suppressed by $\mathrm{KF}$ at $5 \mathrm{~min}$. Moreover, the phosphorylation of p85/PI3K, a downstream substrate of Syk and Src involved in regulating the NF- $\kappa \mathrm{B}$ activation pathway $[2,49,50]$, was also similarly diminished (Figure 3(b) left panel), indicating that the Syk/Src-mediated NF- $\kappa$ B activation pathway could be targeted by KF. To determine whether $\mathrm{KF}$ is able to directly suppress the kinase activities of Src and Syk, enzyme assays were conducted with purified Src and Syk. Intriguingly, $100 \mu \mathrm{M}$ of KF clearly blocked the activity of these enzymes (Figure 3(c)). Using an overexpression strategy with 


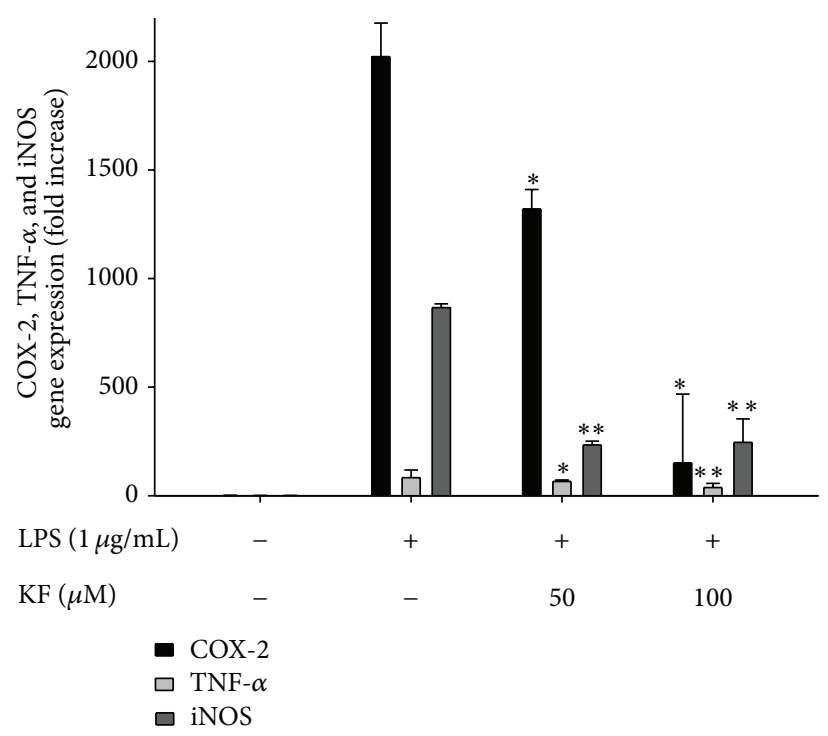

(a)

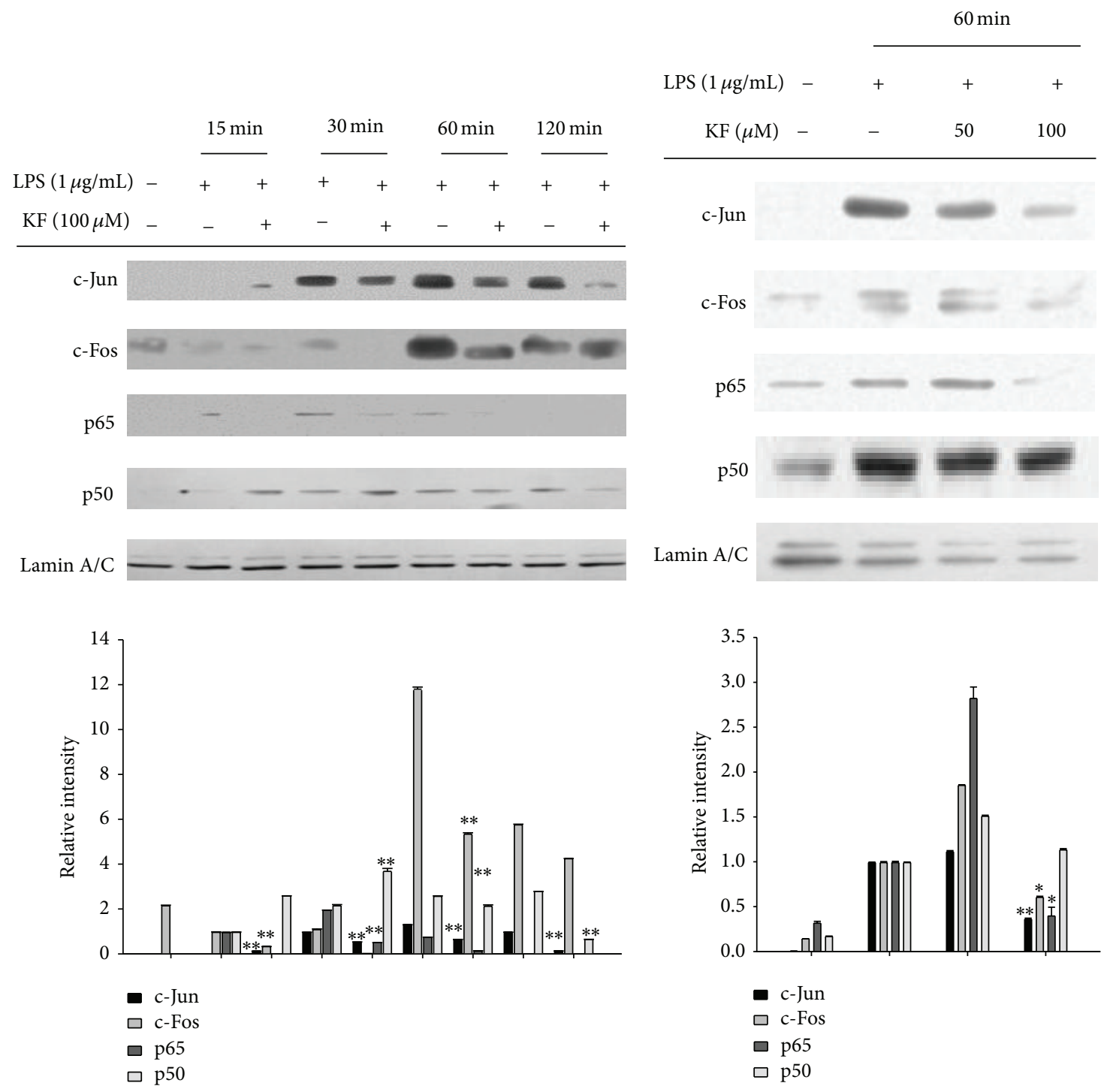

(b)

Figure 2: Continued. 

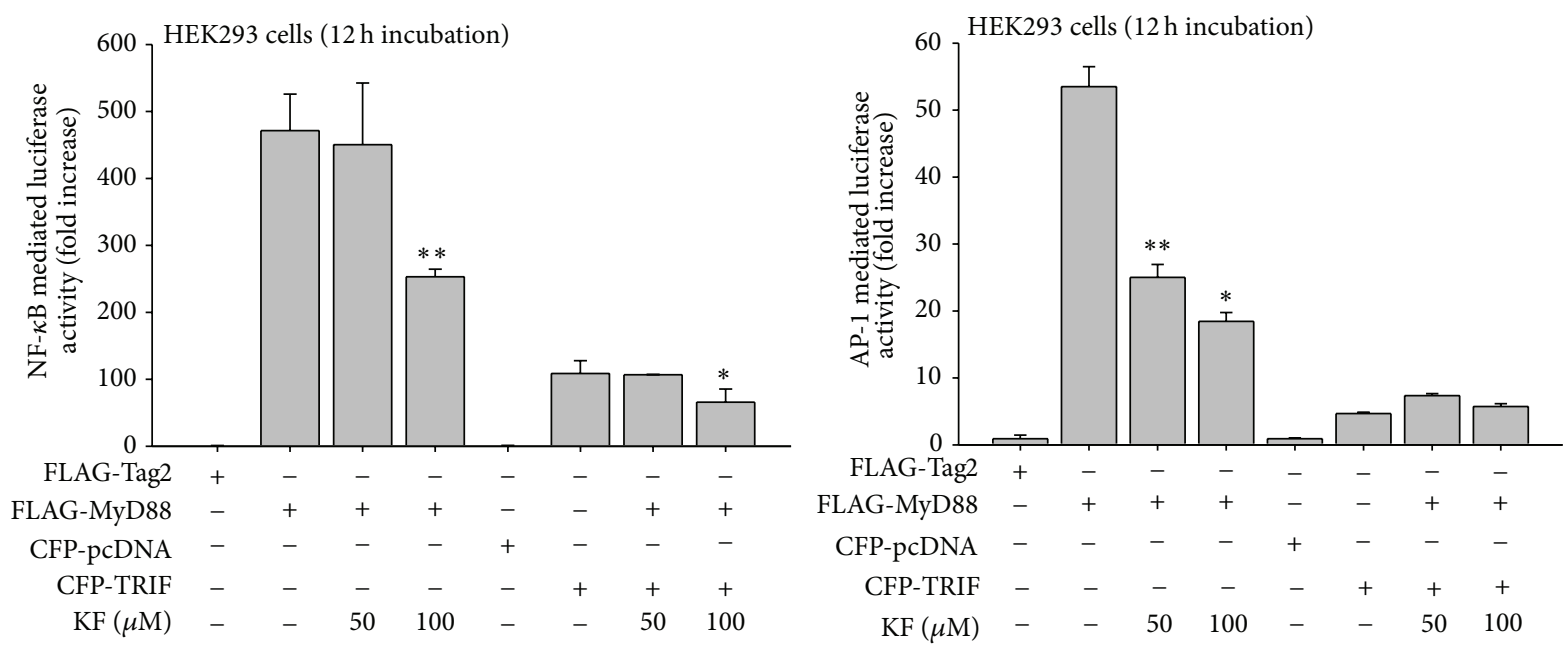

(c)

FIGURE 2: The effects of KF on iNOS, COX-2, and TNF- $\alpha$ gene expression and transcriptional regulation in LPS-treated RAW264.7 cells. (a) RAW264.7 cells $\left(5 \times 10^{6}\right.$ cells $\left./ \mathrm{mL}\right)$ were incubated with LPS $(1 \mu \mathrm{g} / \mathrm{mL})$ in the presence or absence of KF for 6 h. iNOS, COX-2, and TNF- $\alpha$ mRNA levels were determined using real-time PCR. (b) RAW264.7 cells $\left(5 \times 10^{6}\right.$ cells $\left./ \mathrm{mL}\right)$ were incubated with LPS $(1 \mu \mathrm{g} / \mathrm{mL})$ in the presence or absence of KF for the indicated times. After preparing the nuclear fractions, the translocated levels of total transcription factors (p65, p50, c-Fos, and c-Jun) were identified using immunoblot analyses. (c) HEK293 cells cotransfected with the NF- $\kappa$ B-Luc or AP-1-Luc ( $1 \mu \mathrm{g} / \mathrm{mL}$ each) and $\beta$-gal (as a transfection control) plasmid constructs were treated with KF in the presence or absence of adaptor molecule (MyD88 or TRIF) for $12 \mathrm{~h}$. Luciferase activity was determined using luminometry. Relative intensity was calculated using total levels by the DNR Bio-Imaging System. All of the data are expressed as the mean \pm SD of experiments that were performed with six or three (b) samples. ${ }^{*} P<0.05$ and ${ }^{* *} P<0.01$ compared to the control group.

Syk, which showed an increased kinase inhibitory pattern, we also validated that increased autophosphorylation levels of Syk from overexpressed Myc-Syk were also decreased by KF similar to inhibition levels by the Syk inhibitor piceatannol (Picea) (Figure 3(d)). In addition, Syk-induced NF$\kappa \mathrm{B}$ mediated luciferase activity was also reduced by $\mathrm{KF}$ (Figure 3(e)), indicating that Syk can be directly suppressed by KF at the enzyme and related functional levels. Meanwhile, the PP2 and Picea, inhibitors of Src and Syk, respectively, exerted clear anti-inflammatory effects by diminishing the production levels of $\mathrm{NO}$ and $\mathrm{PGE}_{2}$ (Figure 3(f)).

Since LPS-induced translocation of c-Jun and c-Fos (Figure 2(b) left panel) and MyD88-dependent AP-1 activation were reduced by $\mathrm{KF}$, the inhibitory effect of $\mathrm{KF}$ on upstream signaling for AP-1 activation was examined. As Figure 4(a) shows, the phosphorylation of JNK and p38 was inhibited by $\mathrm{KF}$ at 30 and $60 \mathrm{~min}$, indicating that the activity of upstream kinases for JNK and p38 could also be regulated by KF. In fact, KF suppressed the phosphorylation of MKK3 and MKK4 kinases at 5, 15, 30, and $60 \mathrm{~min}$ (Figure 4(b)). Because IRAK1, IRAK4, and TAK1 are known as the upstream enzymes responsible for phosphorylating MAPK kinases [51], although these enzymes are also involved in the activation of $\mathrm{NF}-\kappa \mathrm{B}$ pathway, we investigated the phosphorylation pattern of these proteins. Interestingly, the level of phospho-TAK1 was diminished at $5 \mathrm{~min}$, while the degradation of IRAK1 and IRAK 4 at 2 and $3 \mathrm{~min}$ by LPS was restored by treatment with 50 and $100 \mu \mathrm{M}$ of $\mathrm{KF}$, respectively (Figure $4(\mathrm{c})$ ). Finally, the ability of KF to directly suppress IRAK1 and IRAK 4 enzyme activity was examined using enzyme assays.
As expected, KF blocked the catalytic activity of IRAK1 and IRAK4 (Figure 4(d)), implying that these enzymes are directly targeted and the protein tyrosine kinases Src and Syk were suppressed (Figure 3(c)). Furthermore, inhibitors (SB203580 and SP600125) of p38 and JNK pathways significantly inhibited the production of $\mathrm{PGE}_{2}$ but not $\mathrm{NO}$ (Figure 4(e)), indicating that suppression of p38 and JNK by $\mathrm{KF}$ could contribute to the decrease in $\mathrm{PGE}_{2}$ production.

\section{Discussion}

$\mathrm{KF}$, an abundant flavonoid, is involved in two target inhibitory pathways in inflammation-inducing macrophages. KF inhibited the nuclear translocation of the redox-specific transcription factors, NF- $\kappa$ B and AP-1 (Figure 2(b)), which play critical roles in the induction of inflammatory genes [52]. These results strongly suggest that the upstream enzymes regulating the translocational activation of NF- $\kappa$ B and AP1 might be directly targeted by KF. In fact, immunoblotting analyses, molecular biological approaches, and kinase assays strongly indicate that $\mathrm{KF}$ is able to directly suppress the kinase activities of Src, Syk, IRAK1, and IRAK4 (Figures 3(c) and 4(d)). In addition, a suppressive activity of KF was linked to the suppression of subsequent downstream pathways comprised of $\mathrm{I} \kappa \mathrm{B} \alpha$ or $\mathrm{MKK} 3 / 4, \mathrm{JNK}$, and $\mathrm{p} 38$ (Figures 3(a) and 4(a), top panel, and Figure 4(b)), which are involved in the modulation of NF- $\kappa \mathrm{B}$ and AP-1 activation $[2,49]$.

Thus far, only a few papers have reported the molecular pharmacological targets of KF. It was reported that the $90 \mathrm{kDa}$ 

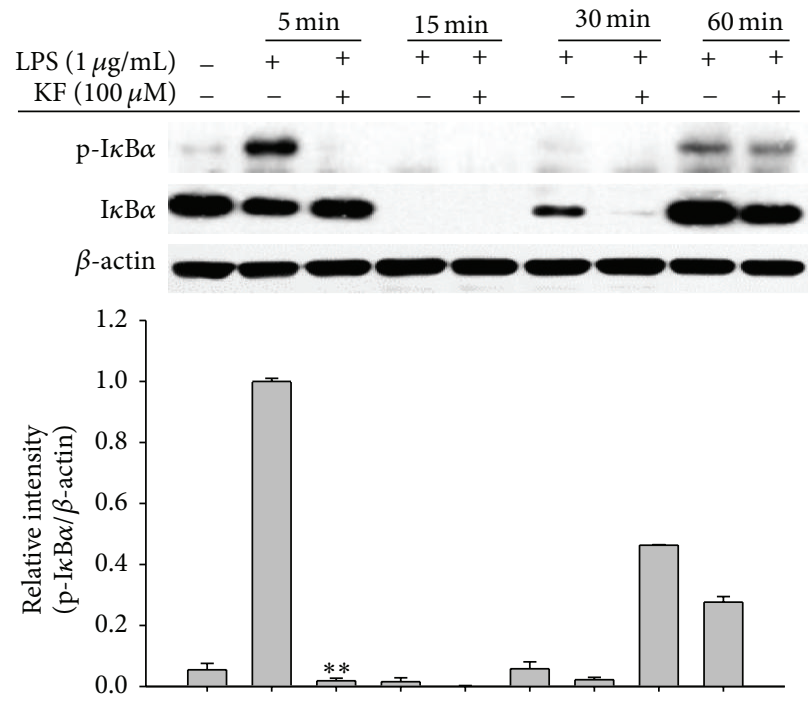

(a)

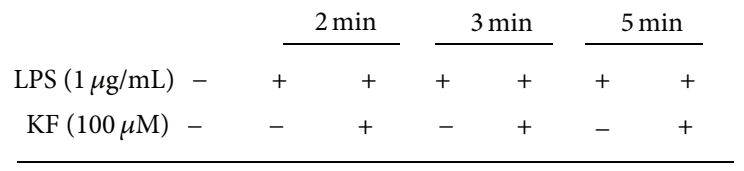

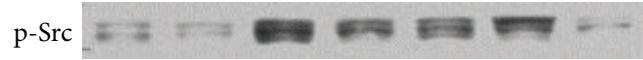

Src

p-Syk
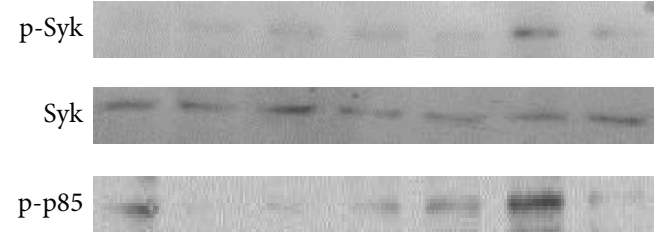

p85

$\beta$-actin

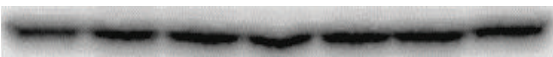

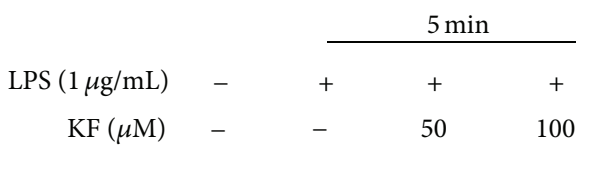

$\mathrm{p}-\mathrm{Sr}$

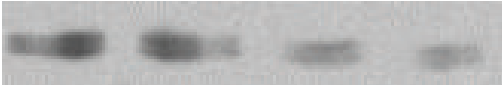

Src

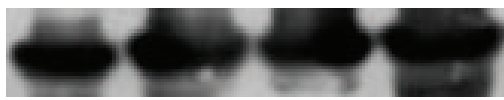

p-Syk

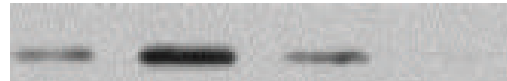

Syk

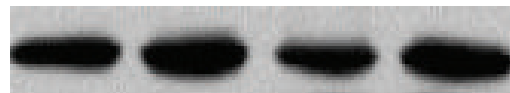

$\beta$-actin
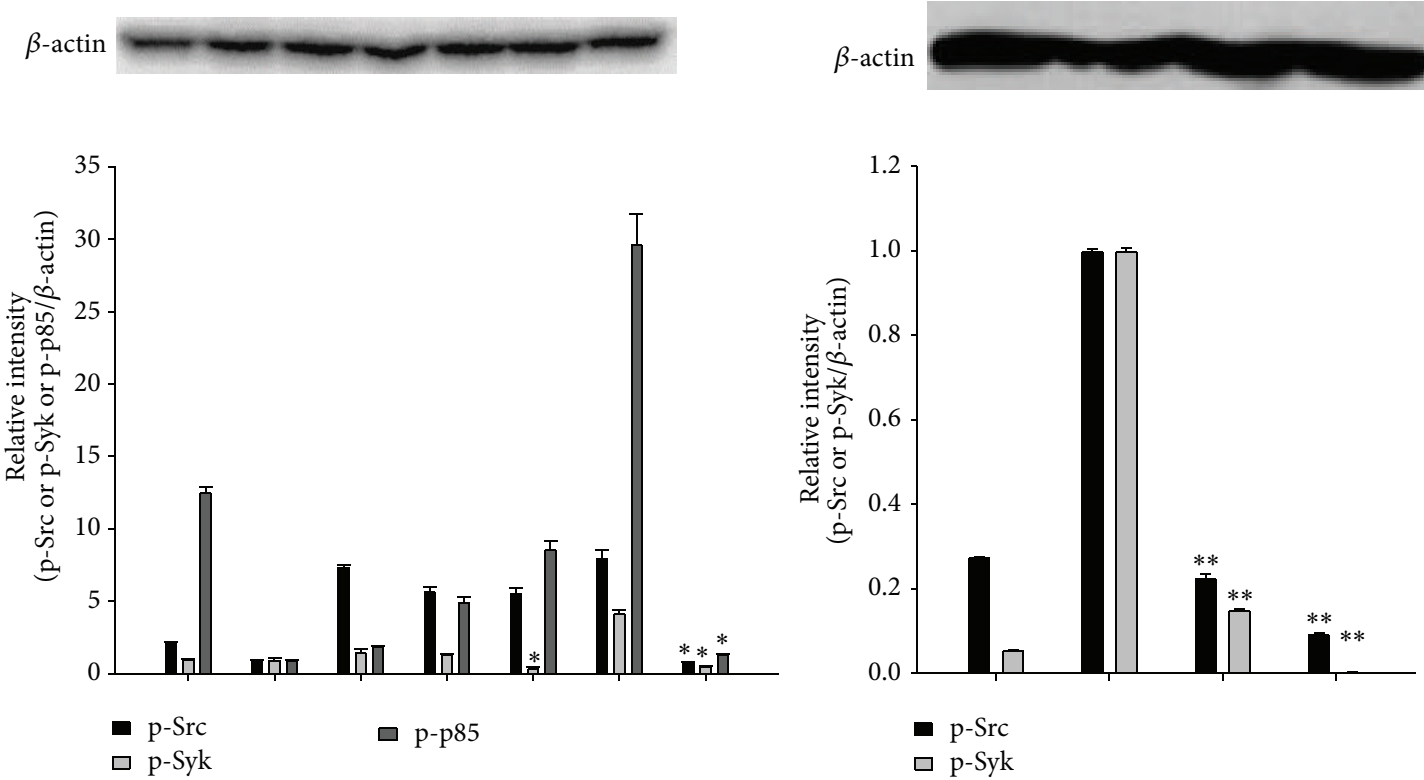

(b)

Figure 3: Continued. 


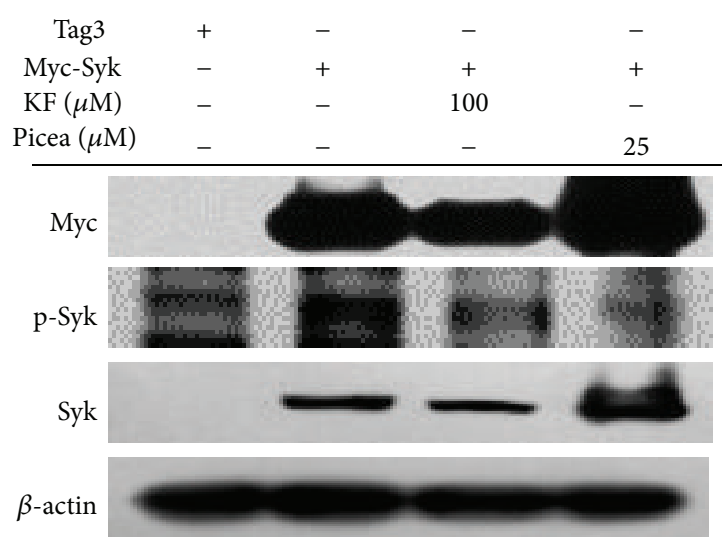

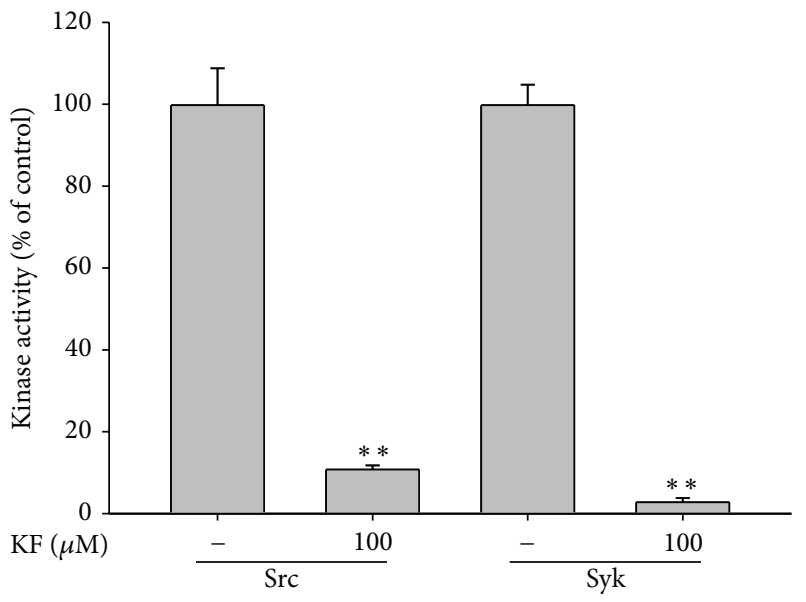

(c)

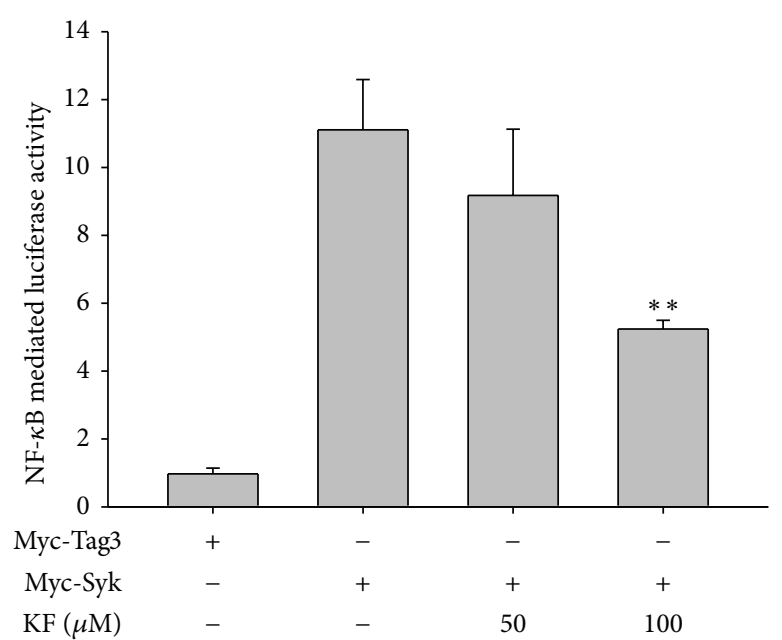

(e)

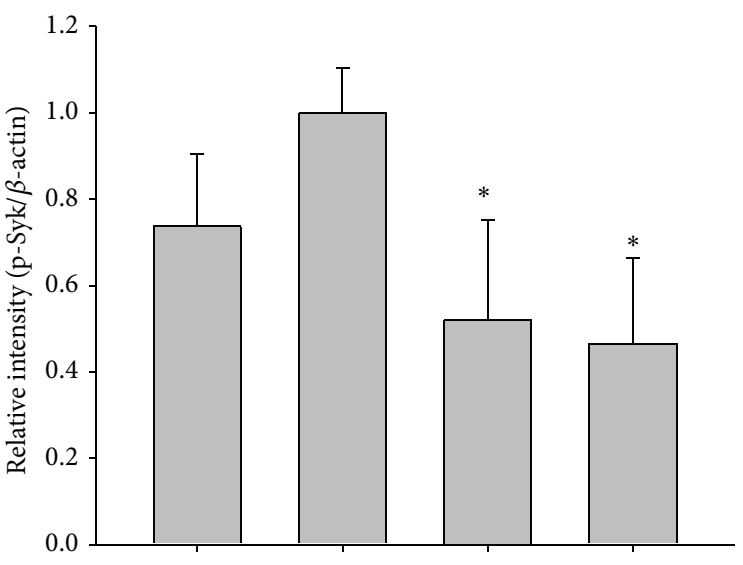

(d)

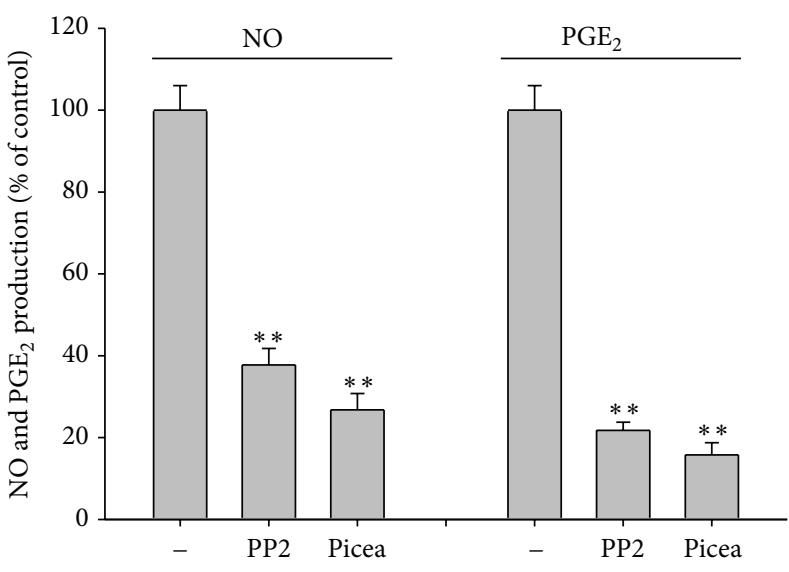

(f)

Figure 3: The effects of KF on NF- $\kappa$ B activation signaling. (a and b) RAW264.7 cells $\left(5 \times 10^{6}\right.$ cells $\left./ \mathrm{mL}\right)$ were incubated with LPS $(1 \mu \mathrm{g} / \mathrm{mL})$ in the presence or absence of KF for the indicated times. After preparing the whole lysates, the levels of total or phosphorylated I $\kappa$ B $\alpha$, Src, Syk, and p85 were identified using immunoblot analyses. (c) The inhibitory effects of KF on Src and Syk activity were determined using a conventional kinase assay with purified Src and Syk. (d) HEK293 cells transfected with Myc-Syk cDNA $(1 \mu \mathrm{g} / \mathrm{mL})$ for 24 h were treated with KF or Picea for $12 \mathrm{~h}$. After preparing the whole lysates, the levels of total or phosphorylated Myc, Syk, and $\beta$-actin were identified using immunoblot analyses. (e) HEK293 cells cotransfected with the NF- $\kappa$ B-Luc $(1 \mu \mathrm{g} / \mathrm{mL}$ each) and $\beta$-gal (as a transfection control) plasmid constructs were treated with $\mathrm{KF}$ in the presence or absence of Myc-Syk for $12 \mathrm{~h}$. Luciferase activity was determined using luminometry. (f) The inhibitory effects of PP2 or Picea on the production of $\mathrm{NO}$ or $\mathrm{PGE}_{2}$ were examined using the Griess assay and EIA. Relative intensity was calculated using total levels by the DNR Bio-Imaging System. All of the data are expressed as the mean \pm SD of experiments that were performed with six or three ( $a$, b, c, and d) samples. ${ }^{*} P<0.05$ and ${ }^{* *} P<0.01$ compared to the control group. 

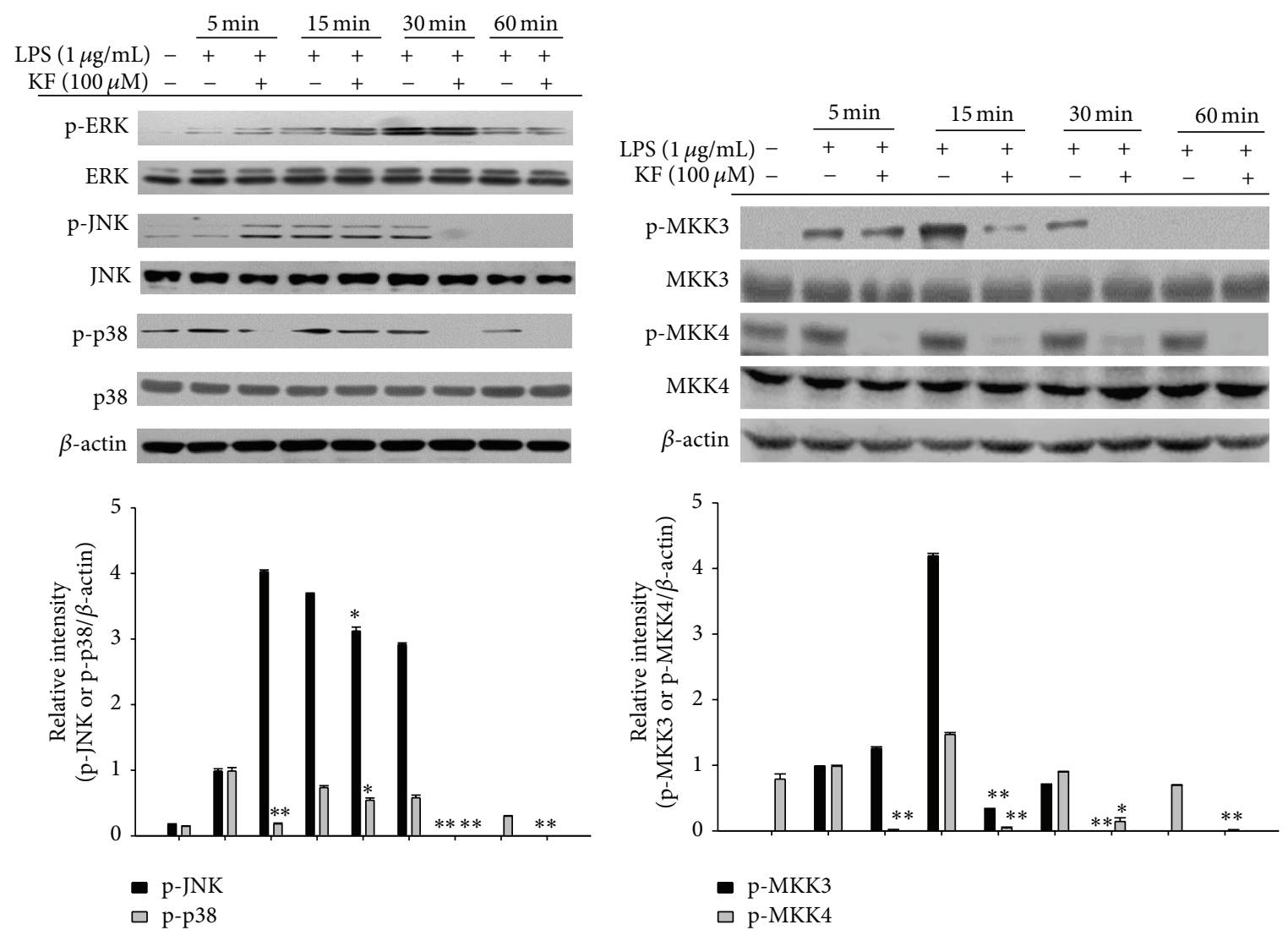

(a)

(b)
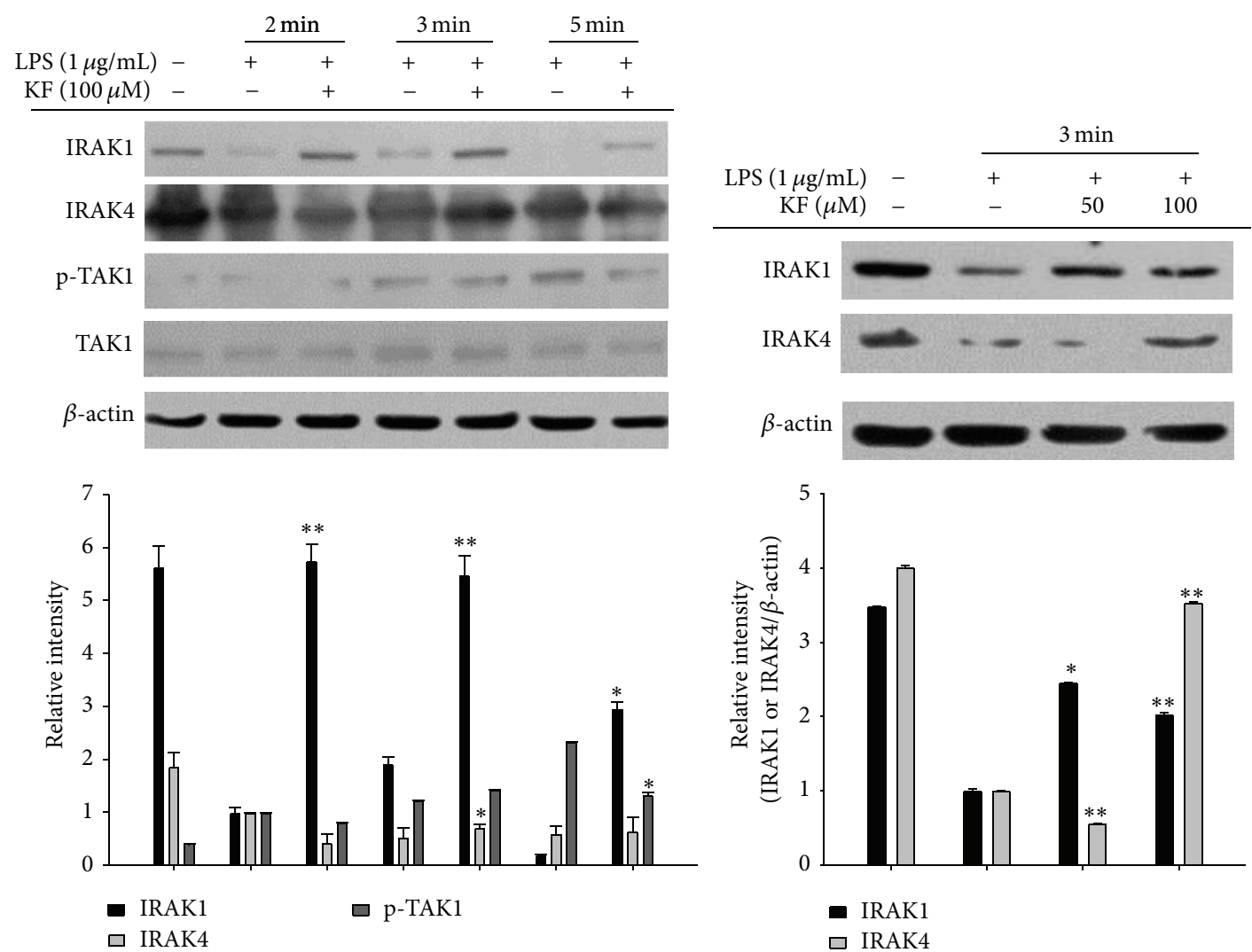

(c)

Figure 4: Continued. 


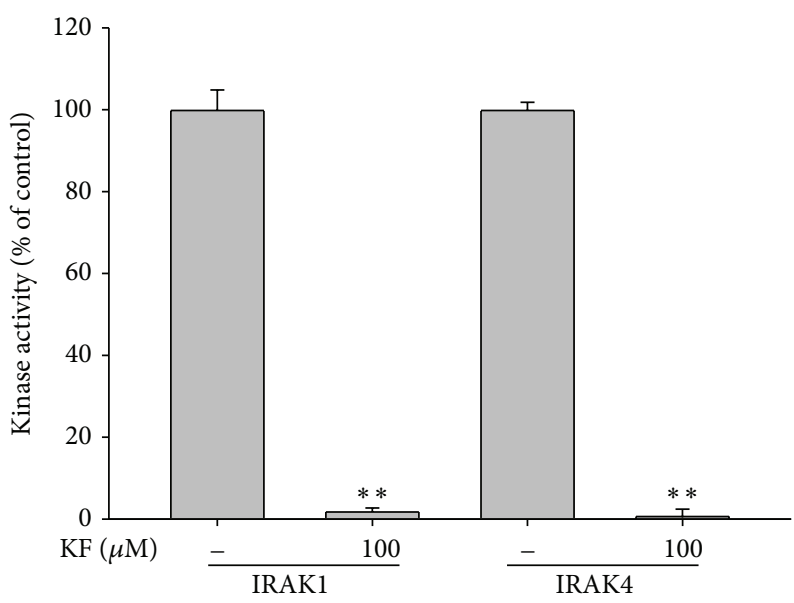

(d)

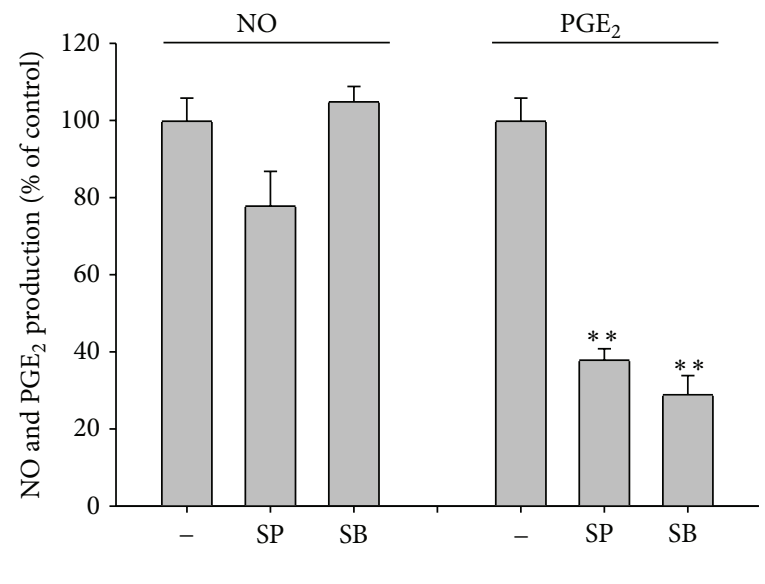

(e)

FIgURE 4: The effects of KF on AP-1 activation signaling. (a, b, and c) RAW264.7 cells $\left(5 \times 10^{6}\right.$ cells $\left./ \mathrm{mL}\right)$ were incubated with LPS $(1 \mu \mathrm{g} / \mathrm{mL})$ in the presence or absence of KF for the indicated times. After preparing the whole lysates, the levels of total or phosphorylated ERK, JNK, p38, MKK3, MKK4, IRAK1, IRAK4, and TAK1 were identified using immunoblot analyses. (d) The inhibitory effects of KF on IRAK1 and IRAK4 activity were determined using a conventional kinase assay with purified IRAK1 and IRAK4. (e) The inhibitory effects of SB or SP on the production of $\mathrm{NO}$ or $\mathrm{PGE}_{2}$ were examined using the Griess assay and EIA. Relative intensity was calculated using total levels by the DNR Bio-Imaging System. All of the data are expressed as the mean \pm SD of experiments that were performed with six or three (a, b, $c$, and d) samples. ${ }^{*} P<0.05$ and ${ }^{* *} P<0.01$ compared to the control group.

ribosomal S6 kinase (RSK) and mitogen and stress-activated protein kinase (MSK) proteins are directly suppressed by KF [19]. Silent information regulator 2 (SIR2), a member of the sirtuin family of $\mathrm{NAD}^{+}$-dependent histone deacetylases, was also found as a direct target protein of $\mathrm{KF}$ [53]. KF also suppressed the kinase activity of right open reading frame2 protein kinase [54]. Phosphatidylinositol 3-kinase was also previously identified as a strong target of KF [21]. In addition to protein kinases, cdc25A tyrosine phosphatase was also inhibited by KF [55]. As a nonsignaling enzyme, fatty acid amide hydrolase was also revealed to be suppressed by KF [56]. Through a direct enzyme assay, we found additional enzymes, including Syk, Src, IRAK1, and IRAK4 (Figures 3(c) and 4(d)), which are involved in the inflammatory signaling events of activated macrophages and monocytes to regulate their production of inflammatory cytokines [2, 49] and $\beta 1 / \beta 2$ integrin-mediated cell migration and adhesion [57]. Indeed, KF strongly suppressed the production and expression of inflammatory mediates such as $\mathrm{NO}, \mathrm{PGE}_{2}$, and TNF- $\alpha$ in LPS-activated macrophages (Figures $1(\mathrm{~b})$ and 2(a)). The adhesion event of U937 cells to FN was also dosedependently diminished by KF (Figure 1(e)). Interestingly, the suppressive activities of these enzymes by KF, as measured by phosphorylation levels of the enzymes, were also found in stomachs treated with $\mathrm{HCl} / \mathrm{EtOH}$ and pancreas exposed with LPS/CA (data not shown), implying that these enzymes play a central role in many different types of in vivo inflammatory symptoms, regardless of inflammatory stimuli. In fact, it is known that damage-associated molecular patterns including HMGB1 and ATP, which are released by sterile, damaged conditions, and pathogen-associated molecular patterns including LPS and peptidoglycan share TLR signaling pathways to generate cellular inflammatory responses [58, 59]. Thus, tissue and cellular damage that occurs under both infected and sterile conditions can induce the activation of NF- $\kappa$ B and AP- 1 via pattern recognition receptors such as TLRs in a similar manner [58]. Previous reports [60-62] and our data strongly indicate that the activation of Src, Syk, IRAK1, and IRAK4 is present in both in vitro and in vivo inflammatory models (Figures 3 and 4, data not shown). In addition, KF strongly inhibits the phosphorylation and subsequent enzyme activity of Src, Syk, IRAK1, and IRAK4, which is linked to its anti-inflammatory action (Figures 3 and 4). Several papers have speculated that KF might bind to the ATP binding sites of kinases, increasing ATP levels attenuated by the inhibitory potency of KF $[54,63]$, although identification of the amino acids of the ATP binding domain that are affected by KF remains unclear and needs further studies. This property could allow KF or other flavonoids broad-spectrum pharmacological activities in numerous molecular and cellular responses. It is known that steroid-backbone drugs (e.g., prednisolone or saponins) display variety of pharmacological actions by antagonizing intracellular glucocorticoid receptor $[64,65]$. However, the fact that there is additive NO inhibitory activity during combination treatment of KF with prednisolone (Figure 1(d) right panel) seems to indicate that KF-mediated direct enzyme inhibition and steroid drug-mediated glucocorticoid receptor antagonism are distinctive pharmacological actions.

In summary, we have shown that KF is capable of effectively suppressing in vitro inflammatory responses as well as its radical scavenging activity. In particular, it was identified that KF serves as a direct inhibitor of Src, Syk, IRAK1, and IRAK4, playing a central role in the activation of NF- $\kappa$ B and AP-1 as summarized in Figure 5. Since KF is included in many edible plants and fruits, we propose that KF-rich fractions 


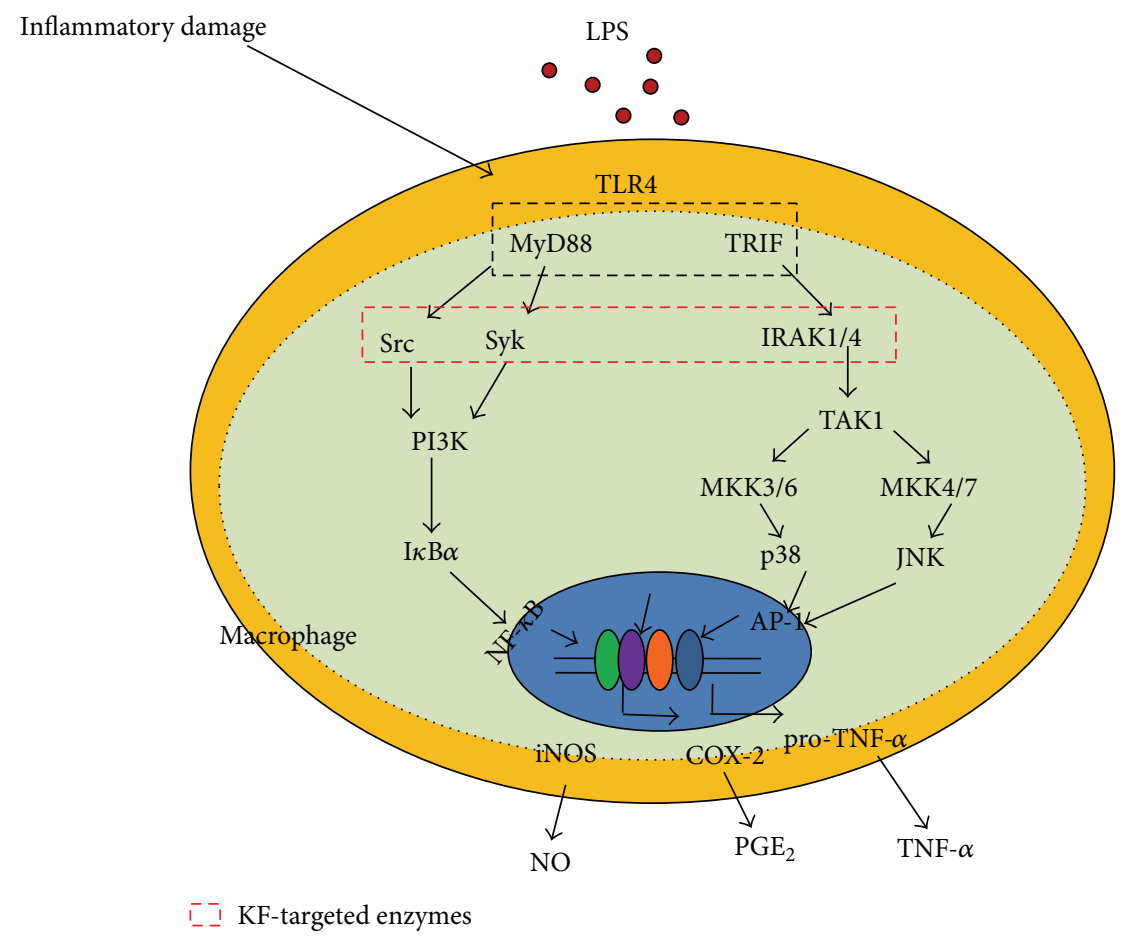

FIGURE 5: Putative KF inhibition pathway in macrophage-mediated inflammatory signaling events.

from edible sources could be applied for the development of functional foods with anti-inflammatory properties.

\section{Abbreviations}

PG: $\quad$ Prostaglandin

NO: $\quad$ Nitric oxide

COX: Cyclooxygenase

iNOS: Inducible NO synthase

TNF- $\alpha$ : Tumor necrosis factor $\alpha$

ERK: Extracellular signal-related kinase

TLR: Toll-like receptors

MAPK: Mitogen activated protein kinase

NF- $\kappa$ B: Nuclear factor $-\kappa B$

AP-1: $\quad$ Activator protein-1

JNK: c-Jun N-terminal kinase

EIA: Enzyme immunoassay

ELISA: Enzyme linked immunosorbent assay

MTT: 3-(4,5-Dimethylthiazol-2-yl)-2,5diphenyltetrazolium bromide (a tetrazole)

IRF-3: Interferon regulatory factor-3

DTT: Dithiothreitol

PI3K: Phosphoinositide 3-kinase

LPS: Lipopolysaccharide

RT-PCR: Reverse transcriptase-polymerase chain reaction.

\section{Disclosure}

The authors alone are responsible for the content and writing of the paper.

\section{Conflict of Interests}

The authors report no conflict of interests.

\section{Authors' Contribution}

Shi Hyoung Kim, Jae Gwang Park, and Jongsung Lee contributed equally to this work.

\section{Acknowledgment}

This work was carried out with the support of the "Cooperative Research Program for Agriculture Science \& Technology Development (Project no. PJ009241)," Rural Development Administration, Republic of Korea.

\section{References}

[1] D. W. Hommes and S. J. H. Van Deventer, "Anti- and proinflammatory cytokines in the pathogenesis of tissue damage in Crohn's disease," Current Opinion in Clinical Nutrition and Metabolic Care, vol. 3, no. 3, pp. 191-195, 2000.

[2] Y. S. Yi, Y. J. Son, C. Ryou, G. H. Sung, J. H. Kim, and J. Y. Cho, "Functional roles of syk in macrophage-mediated inflammatory responses," Mediators of Inflammation, vol. 2014, Article ID 270302, 12 pages, 2014.

[3] M.-Y. Kim and J. Y. Cho, "20S-dihydroprotopanaxadiol, a ginsenoside derivative, boosts innate immune responses of monocytes and macrophages," Journal of Ginseng Research, vol. 37, no. 3, pp. 293-299, 2013. 
[4] M. B. Richardson and S. J. Williams, "MCL and mincle: Ctype lectin receptors that sense damaged self and pathogenassociated molecular patterns," Frontiers in Immunology, vol. 5, article 288, 2014.

[5] T. Yu, Y. J. Li, A. H. Bian et al., "The regulatory role of activating transcription factor 2 in inflammation," Mediators of Inflammation, vol. 2014, Article ID 950472, 10 pages, 2014.

[6] Y. Kobayashi, A. Iwata, K. Suzuki et al., "B and T lymphocyte attenuator inhibits LPS-induced endotoxic shock by suppressing Toll-like receptor 4 signaling in innate immune cells," Proceedings of the National Academy of Sciences of the United States of America, vol. 110, no. 13, pp. 5121-5126, 2013.

[7] T. Romacho, C. F. Sánchez-Ferrer, and C. Peiró, "Visfatin/ Nampt: an adipokine with cardiovascular impact," Mediators of Inflammation, vol. 2013, Article ID 946427, 15 pages, 2013.

[8] J. Hofmanová, N. Straková, A. H. Vaculová et al., "Interaction of dietary fatty acids with tumour necrosis factor family cytokines during colon inflammation and cancer," Mediators of Inflammation, vol. 2014, Article ID 848632, 17 pages, 2014.

[9] E. Barreiro, C. Fermoselle, M. Mateu-Jimenez et al., "Oxidative stress and inflammation in the normal airways and blood of patients with lung cancer and COPD," Free Radical Biology and Medicine, vol. 65, pp. 859-871, 2013.

[10] A. Morales-Sánchez and E. M. Fuentes-Pananá, "Human viruses and cancer," Viruses, vol. 6, no. 10, pp. 4047-4079, 2014.

[11] A. B. Porcaro, E. Rubilotta, A. Petrozziello et al., "Chronic inflammation of the prostate type IV with respect to risk of prostate cancer," Archivio Italiano di Urologia e Andrologia, vol. 86, no. 3, pp. 208-211, 2014.

[12] J. M. Calderon-Montano, E. Burgos-Moron, C. Perez-Guerrero, and M. Lopez-Lazaro, "A review on the dietary flavonoid kaempferol," Mini-Reviews in Medicinal Chemistry, vol. 11, no. 4, pp. 298-344, 2011.

[13] A. Y. Chen and Y. C. Chen, "A review of the dietary flavonoid, kaempferol on human health and cancer chemoprevention," Food Chemistry, vol. 138, no. 4, pp. 2099-2107, 2013.

[14] G. Williamson and A. Carughi, "Polyphenol content and health benefits of raisins," Nutrition Research, vol. 30, no. 8, pp. 511-519, 2010.

[15] H. Y. Jeong, G.-H. Sung, J. H. Kim et al., "Syk and Src are major pharmacological targets of a Cerbera manghas methanol extract with kaempferol-based anti-inflammatory activity," Journal of Ethnopharmacology, vol. 151, no. 2, pp. 960-969, 2014.

[16] P. Rajendran, T. Rengarajan, N. Nandakumar, R. Palaniswami, Y. Nishigaki, and I. Nishigaki, "Kaempferol, a potential cytostatic and cure for inflammatory disorders," European Journal of Medicinal Chemistry, vol. 86, pp. 103-112, 2014.

[17] S. S. Chen, A. Michael, and S. A. Butler-Manuel, "Advances in the treatment of ovarian cancer: a potential role of antiinflammatory phytochemicals," Discovery Medicine, vol. 13, no. 68, pp. 7-17, 2012.

[18] S. V. Jovanovic and M. G. Simic, "Antioxidants in nutrition," Annals of the New York Academy of Sciences, vol. 899, pp. 326$334,2000$.

[19] K. Yao, H. Chen, K. Liu et al., "Kaempferol targets RSK2 and MSK1 to suppress UV radiation-induced skin cancer," Cancer Prevention Research, vol. 7, no. 9, pp. 958-967, 2014.

[20] H. Wang, M. Gao, and J. Wang, "Kaempferol inhibits cancer cell growth by antagonizing estrogen-related receptor $\alpha$ and $\gamma$ activities," Cell Biology International, vol. 37, no. 11, pp. 11901196, 2013.
[21] K. M. Lee, D. E. Lee, S. K. Seo et al., "Phosphatidylinositol 3-kinase, a novel target molecule for the inhibitory effects of kaempferol on neoplastic cell transformation," Carcinogenesis, vol. 31, no. 8, pp. 1338-1343, 2010.

[22] M. J. Park, E. K. Lee, H.-S. Heo et al., "The anti-inflammatory effect of kaempferol in aged kidney tissues: the involvement of nuclear factor- $\kappa \mathrm{B}$ via nuclear factor-inducing kinase $/ \mathrm{I} \kappa \mathrm{B}$ kinase and mitogen-activated protein kinase pathways," Journal of Medicinal Food, vol. 12, no. 2, pp. 351-358, 2009.

[23] X. Chen, X. Yang, T. Liu et al., "Kaempferol regulates MAPKs and NF- $\kappa$ B signaling pathways to attenuate LPS-induced acute lung injury in mice," International Immunopharmacology, vol. 14, no. 2, pp. 209-216, 2012.

[24] H. K. Kim, H. R. Park, J. S. Lee, T. S. Chung, H. Y. Chung, and J. Chung, "Down-regulation of iNOS and TNF- $\alpha$ expression by kaempferol via NF- $\kappa \mathrm{B}$ inactivation in aged rat gingival tissues," Biogerontology, vol. 8, no. 4, pp. 399-408, 2007.

[25] A. R. Kim, J. Y. Cho, Y. Zou, J. S. Choi, and H. Y. Chung, "Flavonoids differentially modulate nitric oxide production pathways in lipopolysaccharide-activated RAW264.7 cells," Archives of Pharmacal Research, vol. 28, no. 3, pp. 297-304, 2005.

[26] H.-J. Chen, C.-M. Lin, C.-Y. Lee et al., "Kaempferol suppresses cell metastasis via inhibition of the ERK-p38-JNK and AP1 signaling pathways in U-2 OS human osteosarcoma cells," Oncology Reports, vol. 30, no. 2, pp. 925-932, 2013.

[27] K.-J. Yang, S. Shin, L. Piao et al., "Regulation of 3-phosphoinositide-dependent protein kinase-1 (PDK1) by Src involves tyrosine phosphorylation of PDK1 and Src homology 2 domain binding," The Journal of Biological Chemistry, vol. 283, no. 3, pp. 1480-1491, 2008.

[28] T. Shen, W. S. Yang, Y.-S. Yi et al., "AP-1/IRF-3 targeted anti-inflammatory activity of andrographolide isolated from Andrographis paniculata," Evidence-Based Complementary and Alternative Medicine, vol. 2013, Article ID 210736, 16 pages, 2013.

[29] E.-H. Joh, J.-J. Jeong, and D.-H. Kim, "Inhibitory effect of echinocystic acid on 12-O-tetradecanoylphorbol-13-acetateinduced dermatitis in mice," Archives of Pharmacal Research, vol. 37, no. 2, pp. 225-231, 2014.

[30] D. H. Kim, J. H. Chung, J. S. Yoon et al., "Ginsenoside Rd inhibits the expressions of iNOS and COX-2 by suppressing NF$\kappa \mathrm{B}$ in LPS-stimulated RAW264.7 cells and mouse liver," Journal of Ginseng Research, vol. 37, no. 1, pp. 54-63, 2013.

[31] C. K. Youn, S. J. Park, M. Y. Lee et al., "Silibinin inhibits LPSinduced macrophage activation by blocking p38 MAPK in RAW 264.7 cells," Biomolecules and Therapeutics, vol. 21, no. 4, pp. 258-263, 2013.

[32] J. Y. Cho, D. A. Fox, V. Horejsi et al., "The functional interactions between CD98, $\beta 1$-integrins, and CD147 in the induction of U937 homotypic aggregation," Blood, vol. 98, no. 2, pp. 374-382, 2001.

[33] M.-Y. Kim and J. Y. Cho, "20S-dihydroprotopanaxatriol modulates functional activation of monocytes and macrophages," Journal of Ginseng Research, vol. 37, no. 3, pp. 300-307, 2013.

[34] S. Larrucea, C. González-Rubio, R. Cambronero et al., "Cellular adhesion mediated by factor J, a complement inhibitor: evidence for nucleolin involvement," The Journal of Biological Chemistry, vol. 273, no. 48, pp. 31718-31725, 1999.

[35] Y. G. Lee, W. M. Lee, J. Y. Kim et al., "Src kinase-targeted anti-inflammatory activity of davallialactone from Inonotus xeranticus in lipopolysaccharide-activated RAW264.7 cells," British Journal of Pharmacology, vol. 154, no. 4, pp. 852-863, 2008. 
[36] R. Pauwels, J. Balzarini, M. Baba et al., "Rapid and automated tetrazolium-based colorimetric assay for the detection of antiHIV compounds," Journal of Virological Methods, vol. 20, no. 4, pp. 309-321, 1988.

[37] T. Yayeh, K.-H. Jung, H. Y. Jeong et al., "Korean red ginseng saponin fraction downregulates proinflammatory mediators in LPS stimulated RAW264.7 cells and protects mice against endotoxic shock," Journal of Ginseng Research, vol. 36, no. 3, pp. 263-269, 2012.

[38] C. T. Oh, J. I. Park, Y. R. Jung et al., "Inhibitory effect of Korean Red Ginseng on melanocyte proliferation and its possible implication in GM-CSF mediated signaling," Journal of Ginseng Research, vol. 37, no. 4, pp. 389-400, 2013.

[39] Y. G. Lee, B. M. Chain, and J. Y. Cho, "Distinct role of spleen tyrosine kinase in the early phosphorylation of inhibitor of $\kappa \mathrm{B} \alpha$ via activation of the phosphoinositide-3-kinase and Akt pathways," International Journal of Biochemistry and Cell Biology, vol. 41, no. 4, pp. 811-821, 2009.

[40] R. Zhang, J. Zhu, H.-Z. Cao et al., "Isolation and characterization of LHT-type plant amino acid transporter gene from Panax ginseng Meyer," Journal of Ginseng Research, vol. 37, no. 3, pp. 361-370, 2013.

[41] G.-J. Kang, S.-C. Han, J.-W. Ock, H.-K. Kang, and E.-S. Yoo, "Anti-inflammatory effect of quercetagetin, an active component of immature Citrus unshiu, in HaCaT human keratinocytes," Biomolecules and Therapeutics, vol. 21, no. 2, pp. 138-145, 2013.

[42] S. E. Byeon, Y. G. Lee, B. H. Kim et al., "Surfactin blocks NO production in lipopolysaccharide-activated macrophages by inhibiting NF-kappaB activation," Journal of Microbiology and Biotechnology, vol. 18, no. 12, pp. 1984-1989, 2008.

[43] J.-A. Lee, M.-Y. Lee, I.-S. Shin, C.-S. Seo, H. Ha, and H. K. Shin, "Anti-inflammatory effects of amomum compactum on RAW 264.7 cells via induction of heme oxygenase-1," Archives of Pharmacal Research, vol. 35, no. 4, pp. 739-746, 2012.

[44] T. Shen, J. Lee, M. H. Park et al., "Ginsenoside Rpl, a ginsenoside derivative, blocks promoter activation of iNOS and Cox-2 genes by suppression of an IKK $\beta$-mediated NF- $\kappa \mathrm{B}$ pathway in HEK293 cells," Journal of Ginseng Research, vol. 35, no. 2, pp. 200-208, 2011.

[45] S. B. Song, N. H. Tung, T. H. Quang, N. T. T. Ngan, K. E. Kim, and Y. H. Kim, "Inhibition of TNF- $\alpha$-mediated NF$\kappa \mathrm{B}$ transcriptional activity in HepG2 cells by dammaranetype saponins from Panax ginseng leaves," Journal of Ginseng Research, vol. 36, no. 2, pp. 146-152, 2012.

[46] K. K. Jung, H. S. Lee, J. Y. Cho et al., "Inhibitory effect of curcumin on nitric oxide production from lipopolysaccharideactivated primary microglia," Life Sciences, vol. 79, no. 21, pp. 2022-2031, 2006.

[47] D. Jeong, Y.-S. Yi, G.-H. Sung et al., "Anti-inflammatory activities and mechanisms of Artemisia asiatica ethanol extract," Journal of Ethnopharmacology, vol. 152, no. 3, pp. 487-496, 2014.

[48] J. Y. Lee, Y. G. Lee, J. Lee et al., "Akt Cys-310-targeted inhibition by hydroxylated benzene derivatives is tightly linked to their immunosuppressive effects," The Journal of Biological Chemistry, vol. 285, no. 13, pp. 9932-9948, 2010.

[49] S. E. Byeon, Y.-S. Yi, J. Oh, B. C. Yoo, S. Hong, and J. Y. Cho, "The role of Src kinase in macrophage-mediated inflammatory responses," Mediators of Inflammation, vol. 2012, Article ID 512926, 18 pages, 2012.

[50] S. E. Byeon, T. Yu, Y. Yang et al., "Hydroquinone regulates hemeoxygenase-1 expression via modulation of Src kinase activity through thiolation of cysteine residues," Free Radical Biology and Medicine, vol. 57, pp. 105-118, 2013.

[51] J. Brown, H. Wang, G. N. Hajishengallis, and M. Martin, "TLR-signaling networks: an integration of adaptor molecules, kinases, and cross-talk," Journal of Dental Research, vol. 90, no. 4, pp. 417-427, 2011.

[52] I.-T. Lee and C.-M. Yang, "Inflammatory signalings involved in airway and pulmonary diseases," Mediators of Inflammation, vol. 2013, Article ID 791231, 12 pages, 2013.

[53] S. Ravichandran, N. Singh, D. Donnelly et al., "Pharmacophore model of the quercetin binding site of the SIRT6 protein," Journal of Molecular Graphics and Modelling, vol. 49, pp. 38-46, 2014.

[54] S. Nag, K. M. N. Prasad, A. Bhowmick, R. Deshmukh, and V. Trivedi, "PfRIO-2 kinase is a potential therapeutic target of antimalarial protein kinase inhibitors," Current Drug Discovery Technologies, vol. 10, no. 1, pp. 85-91, 2013.

[55] N. Aligiannis, S. Mitaku, D. Mitrocotsa, and S. Leclerc, "Flavonoids as cycline-dependent kinase inhibitors: inhibition of cdc 25 phosphatase activity by flavonoids belonging to the quercetin and kaempferol series," Planta Medica, vol. 67, no. 5, pp. 468-470, 2001.

[56] L. Thors, M. Belghiti, and C. J. Fowler, "Inhibition of fatty acid amide hydrolase by kaempferol and related naturally occurring flavonoids," British Journal of Pharmacology, vol. 155, no. 2, pp. 244-252, 2008.

[57] T. Georgakopoulos, S. T. Moss, and V. Kanagasundaram, "Integrin CD11c contributes to monocyte adhesion with CD11b in a differential manner and requires Src family kinase activity," Molecular Immunology, vol. 45, no. 13, pp. 3671-3681, 2008.

[58] M. Riva, E. Källberg, P. Björk et al., "Induction of nuclear factor$\kappa \mathrm{B}$ responses by the S100A9 protein is Toll-like receptor-4dependent," Immunology, vol. 137, no. 2, pp. 172-182, 2012.

[59] C. Jin and R. A. Flavell, "Innate sensors of pathogen and stress: linking inflammation to obesity," Journal of Allergy and Clinical Immunology, vol. 132, no. 2, pp. 287-294, 2013.

[60] S. H. Park, E. Roh, H. S. Kim et al., "Inhibition of IRAK-4 activity for rescuing endotoxin LPS-induced septic mortality in mice by lonicerae flos extract," Biochemical and Biophysical Research Communications, vol. 442, no. 3-4, pp. 183-188, 2013.

[61] T. Piegeler, R. O. Dull, G. Hu et al., "Ropivacaine attenuates endotoxin plus hyperinflation-mediated acute lung injury via inhibition of early-onset Src-dependent signaling," BMC Anesthesiology, vol. 14, article 57, 2014.

[62] M. Brenner and P. S. Gulko, "The arthritis severity locus Cia5a regulates the expression of inflammatory mediators including Syk pathway genes and proteases in pristane-induced arthritis," BMC Genomics, vol. 13, no. 1, article 710, 2012.

[63] G. Lolli, G. Cozza, M. Mazzorana et al., "Inhibition of protein kinase CK2 by flavonoids and tyrphostins. A structural insight," Biochemistry, vol. 51, no. 31, pp. 6097-6107, 2012.

[64] D. W. Gilroy and M. Perretti, "Aspirin and steroids: new mechanistic findings and avenues for drug discovery," Current Opinion in Pharmacology, vol. 5, no. 4, pp. 405-411, 2005.

[65] H. J. Kim, P. Kim, and C. Y. Shin, "A comprehensive review of the therapeutic and pharmacological effects of ginseng and ginsenosides in central nervous system," Journal of Ginseng Research, vol. 37, no. 1, pp. 8-29, 2013. 


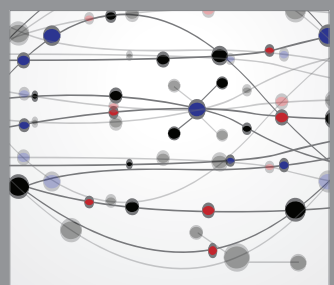

The Scientific World Journal
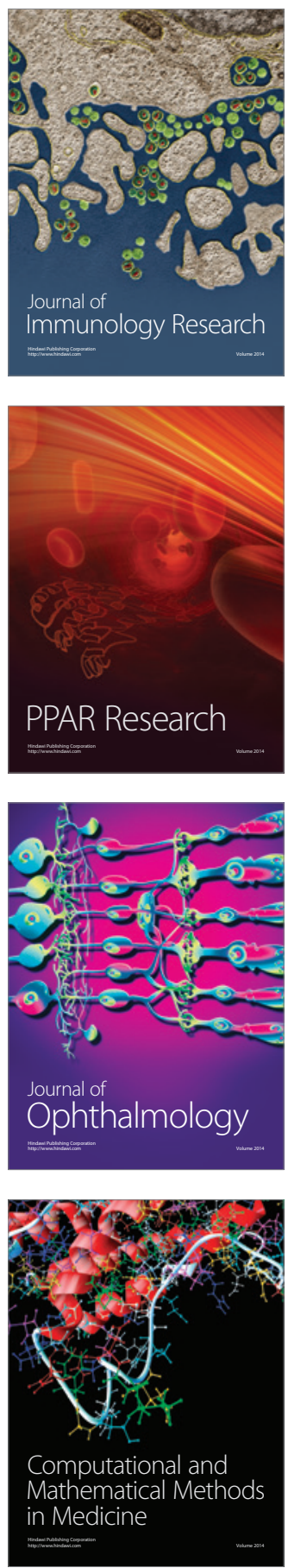

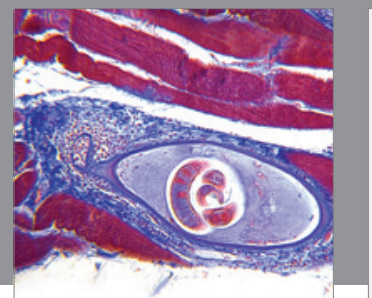

Gastroenterology

Research and Practice
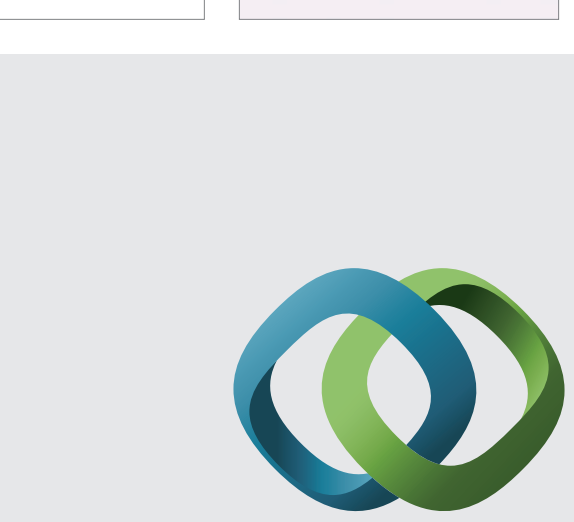

\section{Hindawi}

Submit your manuscripts at

http://www.hindawi.com
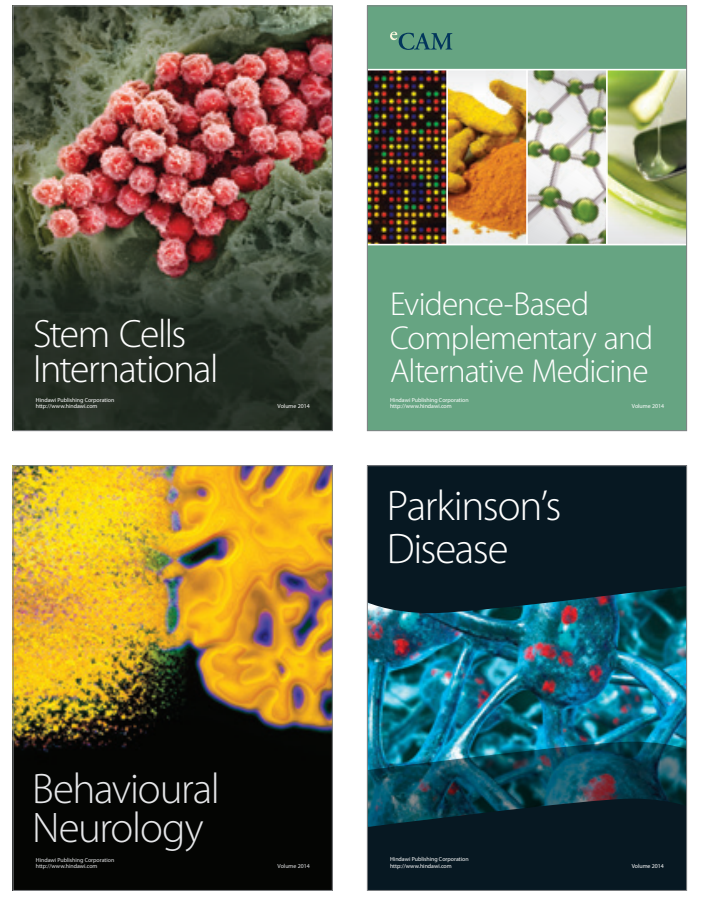
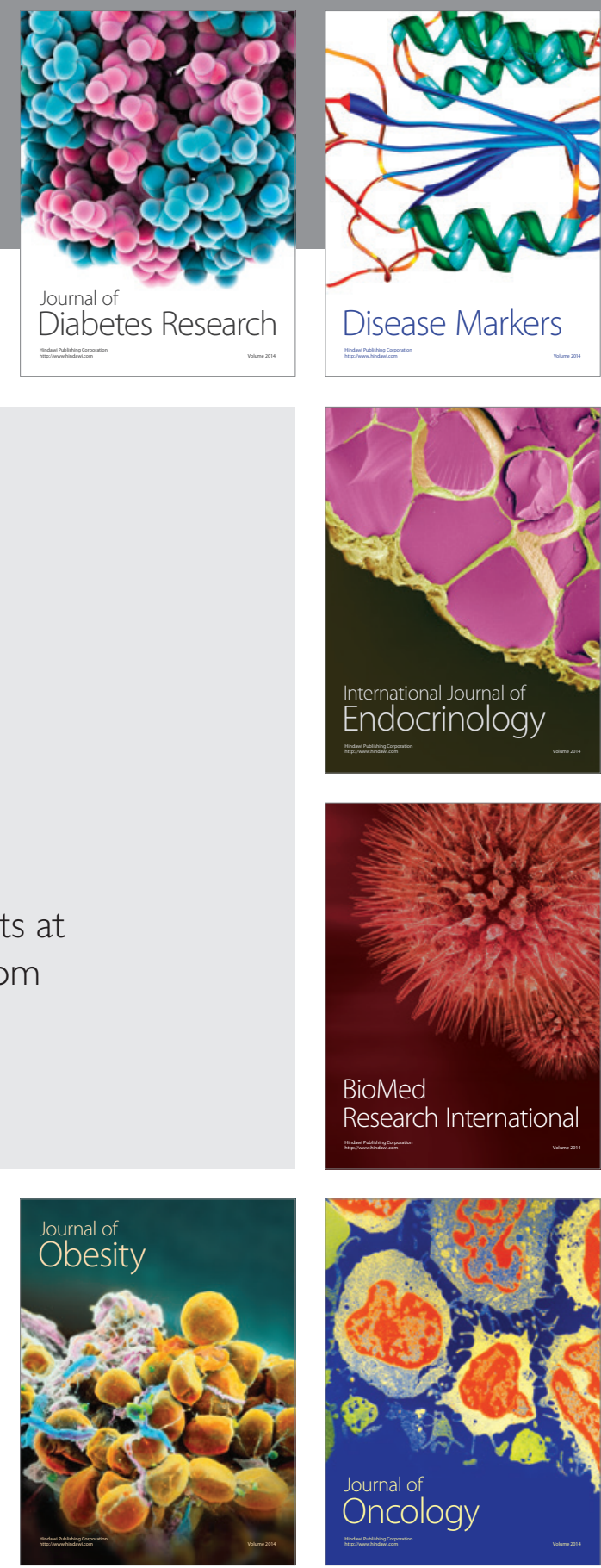

Disease Markers
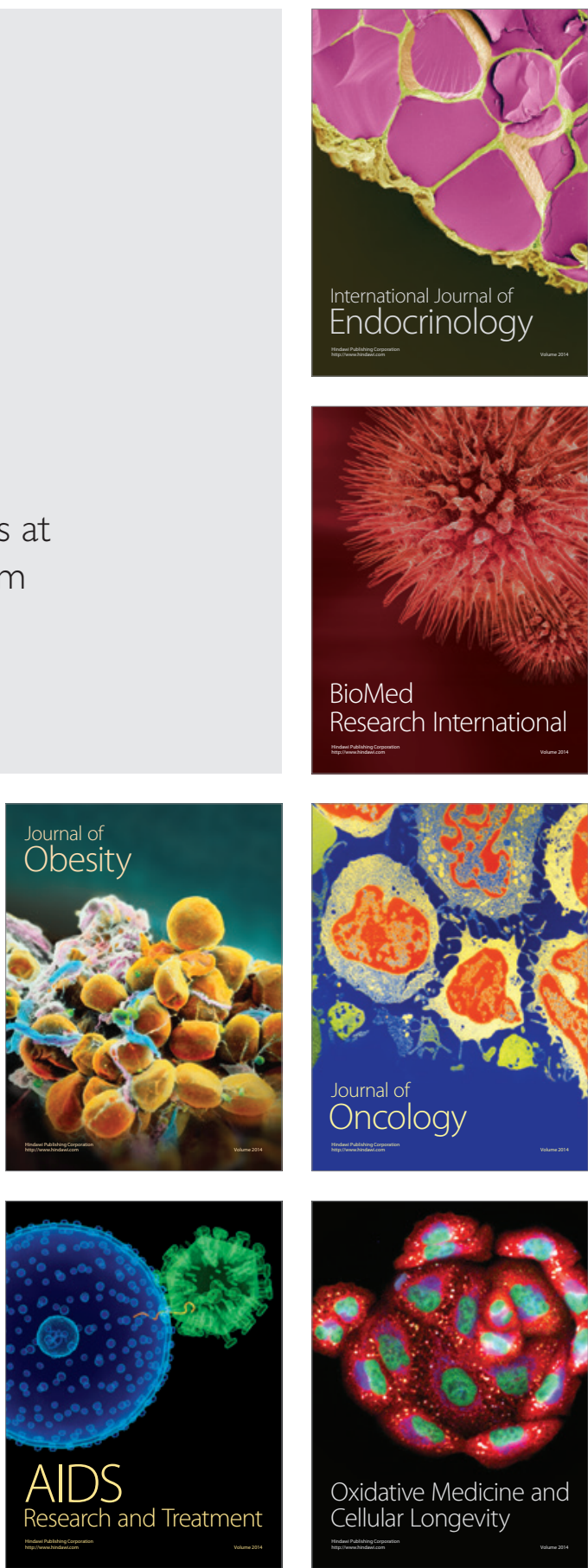